\title{
Vascular Notch proteins and Notch signaling in the peri- implantation mouse uterus
}

\author{
Vascular Cell 7:y I DOI: 10.1186/s13221-015-0034-y I C Li et al.; licensee Publiverse Online S.R.L. 2015 \\ Received: 29 Jul 2015 | Accepted: 17 Jul 2015 | Published: 1 Jul 2015 \\ Shawber Carrie J., Lin Lu, Gnarra Maria, Sauer Mark V., Papaioannou Virginia E., Kitajewski Jan K., \\ Douglas Nataki C. \\ ${ }^{+}$Contributed equally ${ }^{@}$ Corresponding author
}

\section{Abstract}

\section{Background}

Angiogenesis is essential for uterine decidualization, the progesterone-mediated transformation of the uterus allowing embryo implantation and initiation of pregnancy. In the current study, we define the vasculature, expression of Notch proteins and Notch ligands, and Notch activity in both endothelial cells and vascularassociated mural cells of blood vessels in the pre-implantation endometrium and post-implantation decidua of the mouse uterus.

\section{Methods}

We used immunofluorescence to determine the expression of Notch in endothelial cells and mural cells by costaining for the endothelial cell marker, CD31, the pan-mural cell marker, platelet-derived growth factor receptor beta (PDGFR- $\beta$ ), the pericyte markers, neural/glial antigen 2 (NG2) and desmin, or the smooth muscle cell marker, alpha smooth muscle actin (SMA). A fluorescein isothiocyanate-labeled dextran tracer, was used to identify functional peri-implantation vasculature. $C B F: H 2 B$-Venus Notch reporter transgenic mice were used to determine Notch activity.

\section{Results}

Notch signaling is observed in endothelial cells and pericytes in the peri-implantation uterus. Prior to implantation, Notch1, Notch2 and Notch4 and Notch ligand, Delta-like 4 (Dll4) are expressed in capillary endothelial cells, while Notch3 is expressed in the pericytes. Jagged 1 is expressed in both capillary endothelial cells and pericytes. After implantation, Notch1, Notch4 and Dll4 are expressed in endothelial cells of newly formed decidual capillaries. Jagged1 is expressed in endothelial cells of spiral arteries and a subset of decidual pericytes. Notch proteins are not expressed in lymphatic vessels or macrophages in the peri-implantation uterus.

\section{Conclusions}

We show Notch activity and distinct expression patterns for Notch proteins and ligands, suggesting unique roles for Notch1, Notch4, Dll4, and Jag1 during decidual angiogenesis and early placentation. These data set the stage for loss-of-function and gain-of-function studies that will determine the cell-type specific requirements for Notch proteins in decidual angiogenesis and placentation.

\section{Keywords}

Notch - Dll4 - Jagged1 - Endothelial cells - Pericytes - Decidua - Angiogenesis - Implantation

\section{Introduction}


Angiogenesis, the formation of new vessels from pre-existing vasculature, is critical in the uterine endometrium for embryo implantation, maintenance of early pregnancy, and development of the placenta. After fertilization, angiogenesis within the uterus occurs simultaneously with stromal cell decidualization, the rapid proliferation and differentiation of endometrial stromal fibroblasts into glycogen and lipid rich decidual cells [ 1-4]. In mice and humans, the uterine decidua supports early pregnancy prior to placenta development. The decidua serves as a scaffold for the newly formed decidual vascular plexus, as well as the maternal spiral arteries that are remodeled by embryo-derived trophoblasts during placenta formation. The decidual vascular plexus serves as the first exchange apparatus between the maternal circulation and the embryo and is necessary to maintain pregnancy prior to placenta formation [ 5-7]. In mice, inadequate decidual vascular development results in pregnancy failure by mid-gestation $[7,8]$. In humans, inadequate decidual vascular development is associated with implantation failure, first trimester miscarriages, and abnormal placenta formation and function which leads to preeclampsia and intrauterine growth restriction [ 4,9]. Ovarian estrogen and progesterone regulate decidua formation; however, the underlying molecular signaling pathways active in decidual angiogenesis have not as yet been fully characterized.

Sprouting angiogenesis is a multi-step process that begins with endothelial cells (ECs) sprouting out from mature vessels. ECs then migrate and proliferate to form a new sprout consisting of a tip cell at the front and neighboring stalk cells. New sprouts form capillary loops to create the vessel lumen and recruit vascular mural cells, which include pericytes and vascular smooth muscle cells (vSMCs), necessary for vessel stabilization [

10]. Well-known regulators of angiogenesis during development and adult life include the vascular endothelial growth factor (VEGF) and Notch signaling pathways. In mice and non-human primates, VEGF activates VEGF receptors (VEGFR) to mediate increased uterine vascular permeability and decidual angiogenesis required for embryo implantation [ 5, 6, 11]. We have shown that inhibition of VEGFR-2, blocks decidual angiogenesis observed at embryonic day 7.5 (E7.5) and results in embryonic lethality prior to E10.5 [ 7]. Whereas continuous VEGFR-1 blockade significantly reduces decidual angiogenesis [12] and VEGFR-3 inhibition moderately reduces decidual angiogenesis [ 7], neither VEGFR-1 nor VEGFR-3 blockade has a notable negative effect on pregnancy prior to E10.5.

VEGF and Notch signaling pathways interact to coordinate developmental and postnatal angiogenesis [ 1315], angiogenesis in tumors [ 16], and angiogenesis modeled in vitro [ 17-21]. Notch proteins (Notch1, Notch2, Notch3, and Notch4) are single-pass transmembrane receptors that interact with membrane-bound ligands of the Delta-like (Dll) (Dll1, Dl13, Dl14) and Jagged (Jag1 and Jag2) families in adjacent cells [ 22, 23]. In mice, Notch 1 and Notch 4 are expressed in endothelium of the developing vasculature [ 24-26] and Notch3 is expressed in mural cells, pericytes and vSMCs [ 26-28]. In tissues, such as the developing postnatal retina Notch ligand, Dll1 and Dll4 are expressed in ECs, while Jag1 is expressed in both ECs and vascular mural cells [ 23,29]. Genetic studies demonstrate that Notch proteins and ligands are essential for embryonic vascular development [ 30-32] and maturation of vSMCs in mice [ 33, 34] and humans [ 35, 36].

Given the interactions between the Notch and VEGF signaling pathways in vascular development, Notch signaling likely functions in mammalian decidual angiogenesis to coordinate EC VEGFR signaling. A role for Dll4 in vascular development and differentiation in the decidua has recently been shown. Dll4 mediates decidual angiogenesis through induction of a tip/stalk phenotype in decidual ECs, suggesting a requirement for Notch signaling for proper decidual vascular development [ 37]. However, a comprehensive analysis of the expression of Notch proteins and ligands in decidual angiogenesis has yet to be described. The goal of this study is to define the expression of Notch proteins and Notch ligands in the peri-implantation uterus as a framework for genetic studies that will identify cell-type specific requirements for Notch signaling in decidual angiogenesis and placenta formation. Herein, we characterize the distribution of blood and lymphatic vessels, vascular associated mural cells, and macrophages in the pre- and post-implantation mouse uterus and use a fluorescein isothiocyanate (FITC)-labeled dextran tracer to identify the functional peri-implantation vasculature. We determine the expression of Notch proteins, Notch1-4, Notch ligands, Dll4 and Jag1, and Notch activity with respect to ECs and mural cells in the pre- and post-implantation mouse uterus. Our data provide strong support for a role for Notch signaling in decidual angiogenesis and pericyte/EC interactions.

\section{Methods}

\section{Animals}

The Columbia University Institutional Animal Care and Use Committee approved protocols used in animal studies. All mice were maintained on a C57BL/6 background. For assessment of wild type expression patterns, we used C57BL/6J virgin female mice and males of proven fertility (The Jackson Laboratory). The $C B F: H 2 B$ Venus transgenic mouse strain that expresses human histone H2B fused to yellow fluorescent protein (YFP) Venus in response to Notch/CSL transcriptional activation was used to determine Notch activity [ 38]. Mice 
were bred; noon on the day a mating plug was observed was designated embryonic day (E) 0.5. Pieces of uteri and implantation sites from pregnant females at E3.5 and E6.5, respectively, were embedded in Tissue-Tek® O.C.T. ${ }^{\text {TM }}$ Compound (Sakura Fine Technical Co, Ltd, Tokyo, Japan), snap-frozen on dry ice in ethanol and stored at $-80{ }^{\circ} \mathrm{C}$ in methylbutane (Sigma-Aldrich).

\section{Histology, immunohistochemistry (IHC) and immuofluorescence (IF)}

$7 \mu \mathrm{m}$ transverse frozen sections through E3.5 uteri were generated. To visualize implantation sites at E6.5, $7 \mu \mathrm{m}$ frozen sections through uteri/implantation sites, showing inter-embryonic regions and central parts of the decidua, were generated. Implantation was confirmed by hematoxylin and eosin $(\mathrm{H} \& \mathrm{E})$ staining every 5 th section. IHC and IF staining as previously described [ 39] was performed at least 3 times and 5 different uterine sections or implantation sites were analyzed for each antibody. Primary antibodies are listed in Table 1. The specificity of Notch protein and ligand primary antibodies was determined by comparing two independent antibodies for identical staining patterns in serial E9.75 and E10.5 tissue sections [ 40], as well as murine ovary sections. For colorimetric IHC, biotin goat anti-rat IgG (BD Biosciences 559286, 1:750), the avidin/biotin blocking kit (Vector SP-2001), the Vectastain ABC kit and DAB substrate kit (Vector SK-4100) were used. Sections were counterstained with hematoxylin. Secondary antibodies for IF are listed in Table 1. Vectashield containing with 4', 6-diamidino-2-phenylindole (DAPI) (Vector H-1200) was used for nuclear visualization and mounting.

\section{Table 1}

Antibodies for analysis of the pregnant mouse uterus

\begin{tabular}{|c|c|c|c|c|}
\hline Name & Host & Company & $\begin{array}{l}\text { Catalog } \\
\text { Number }\end{array}$ & Concentration \\
\hline \multicolumn{5}{|l|}{ Primary antibodies } \\
\hline $\mathrm{CD} 11 \mathrm{~b}$ & Rat & Abcam & ab8878 & $1: 500$ \\
\hline CD31 & Rat & BD Biosciences & 553370 & $1: 350$ \\
\hline Desmin & Rabbit & Abcam & ab15200 & $1: 500$ \\
\hline Dl14 & Goat & R\&D Systems & AF1389 & $1: 100$ \\
\hline $\mathrm{F} 4 / 80$ & Rat & eBioscience & $14-4801$ & $1: 100$ \\
\hline Jagged1 extracellular domain & Goat & R\&D Systems & AF599 & $1: 100$ \\
\hline Hey2 & Rabbit & Abcam & ab25404 & $1: 200$ \\
\hline LYVE1 & Rabbit & Abcam & ab14917 & $1: 1000$ \\
\hline NG2 & Rabbit & Millipore & AB5320 & $1: 750$ \\
\hline Notch1 & Goat & R\&D Systems & AF1057 & $1: 200$ \\
\hline Notch2 & Rabbit & Abcam & Ab8926 & $1: 500$ \\
\hline Notch3 & Rabbit & Abcam & Ab60087 & $1: 50$ \\
\hline Notch4 Rb2-2 & Rabbit & $\begin{array}{l}\text { Dr. Kitajewski's } \\
\text { laboratory }\end{array}$ & & $1: 100$ \\
\hline PDGFR- $\beta$ & Rabbit & Cell Signaling & 3169 & $1: 500$ \\
\hline PDGFR- $\beta$ & Rat & Abcam & Ab91066 & $1: 100$ \\
\hline$\alpha-S M A$ & Mouse & Sigma & C6198 & $1: 850$ \\
\hline \multicolumn{5}{|l|}{ Secondary antibodies } \\
\hline Anti-goat-IgG Alexa-Fluor 594 & Donkey & Invitrogen & A11058 & $1: 800$ \\
\hline $\begin{array}{l}\text { Anti-rabbit-IgG Alexa-Fluor } \\
594\end{array}$ & Donkey & Invitrogen & A21207 & $1: 800$ \\
\hline $\begin{array}{l}\text { Anti-rabbit-IgG Alexa-Fluor } \\
488\end{array}$ & Donkey & Invitrogen & A21206 & $1: 800$ \\
\hline Anti-rat-IgG Alexa-Fluor 594 & Donkey & Invitrogen & A21209 & $1: 800$ \\
\hline Anti-rat-IgG Alexa-Fluor 488 & Donkey & Invitrogen & A21208 & $1: 800$ \\
\hline
\end{tabular}

\section{Dextran perfusion}

Mice were given tail vein injections of $200 \mu \mathrm{l}(25 \mathrm{mg} / \mathrm{mL})$ of FITC-conjugated $40 \mathrm{kDa}$ dextran (Invitrogen D1820) at E3.5 and $10 \mathrm{kDa}$ dextran (Invitrogen D-1845) at E6.5 [ 41-43]. After 10 minutes, animals were euthanized. Uteri and implantation sites were dissected in cold phosphate buffered saline, fixed in Carnoy's solution and embedded in paraffin wax. Sections $(7 \mu \mathrm{m})$ were deparaffinized, rehydrated and mounted in Vectashield medium containing DAPI or stained for Notch1 prior to mounting. Dextran was administered to 3 
mice at each stage. Specific staining was performed at least 3 times and 5 different uterine sections or implantation sites were analyzed at each stage.

\section{Microscopy}

IHC and H\&E staining were examined with a Nikon MICROPHOT-FXA microscope and images were captured using NIS-Elements D3.10 software. Fluorescent images were captured using a Nikon A1 scanning confocal microscope on an Eclipse Ti microscope stand (Nikon Instruments, Melville, NY). Standard lasers and filters were used to image DAPI, AlexaFluor 488, and TRITC. Maximum intensity projections are shown.

\section{Results}

\section{Characterization of blood vessels in the pre-implantation murine uterus}

Functional blood vessels, including capillaries, arterioles, and venules, consist of two key interacting cell types, ECs and vascular mural cells. ECs form the inner lining of the vessel wall and vascular mural cells, which include pericytes and vSMCs, surround the endothelial tube, providing structural support, regulating vessel diameter and aiding in the regulation of blood flow [44]. To characterize the pattern of vascular mural cells and functional blood vessels in the uterus before embryo implantation, we determined the distribution of ECs and mural cells by co-staining for the EC marker, CD31 and the pan-mural cell marker, platelet-derived growth factor receptor beta (PDGFR- $\beta$ ), the pericyte markers, neural/glial antigen 2 (NG2) and desmin, or the vSMC marker, alpha smooth muscle actin (SMA). Endometrial vessel functionality was determined by intravenous administration of FITC-labeled $40 \mathrm{kDa}$ dextran into the tail vein of pregnant females followed by visualization of labeled dextran in uterine vessels, indicating vessel perfusion (Fig. 1).

Fig. 1
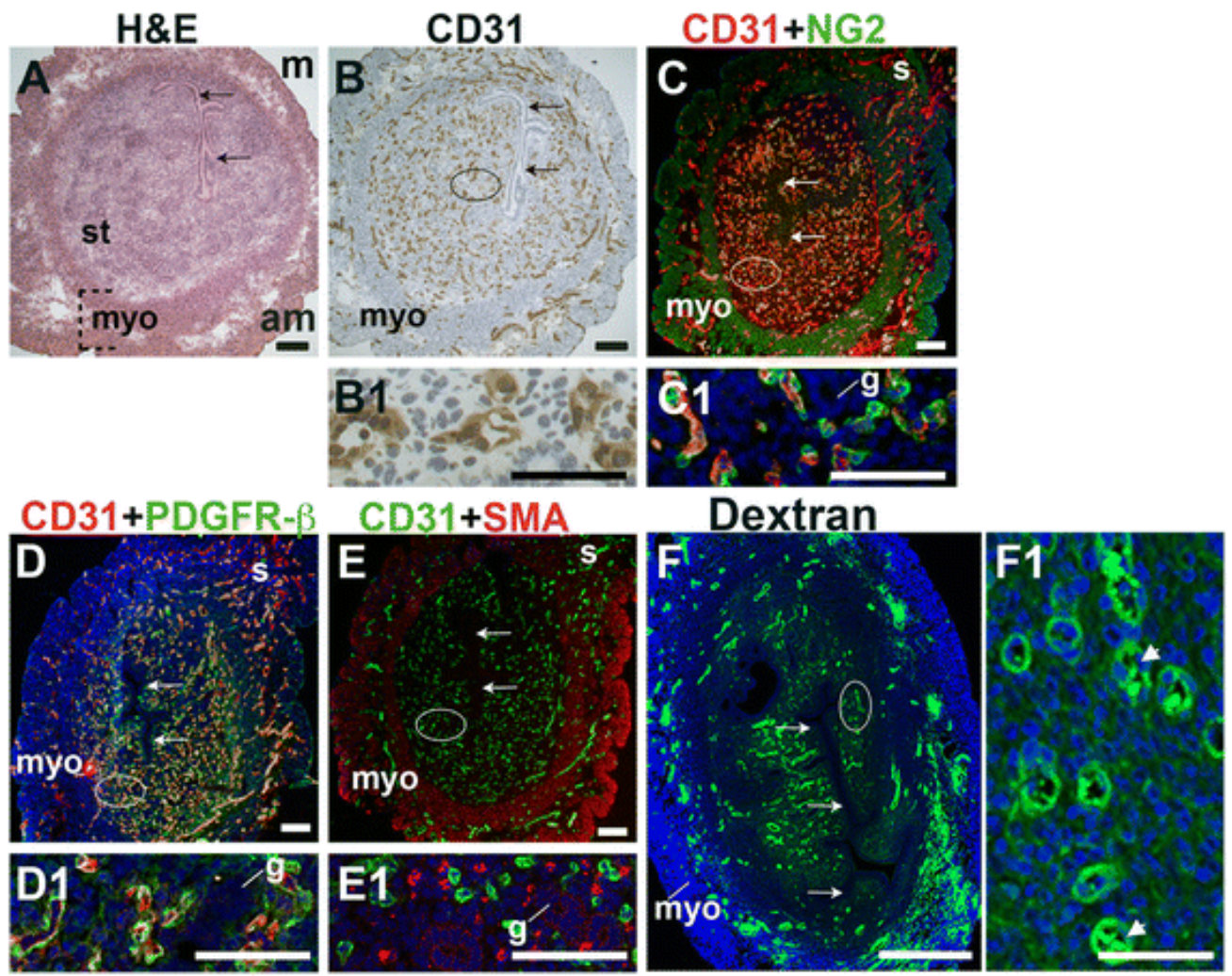

Characterization of blood vessels in the pre-implantation murine uterus. H\&E, IHC, double staining IF and fluorescently labeled dextran in E3.5 transverse uterine sections. Ovals indicate areas of the uteri magnified $(\mathrm{B} 1-\mathrm{F} 1)$. The orientation is the same for all panels; anti-mesometrial $(\mathrm{am})$ is at the bottom and mesometrial (m) is at the top. (A) H\&E at E3.5 highlighting the luminal epithelium (arrows), inner circular and outer longitudinal myometrium [dashed bracket (myo)], and endometrial stroma (st). (B) CD $31^{+}$ECs are detected throughout the endometrial stroma and myometrium. (C) CD31 and NG2 staining. $\mathrm{NG}^{+}$mural cells are associated with CD $31^{+}$ECs in the stroma, myometrium and serosa (s). (D) CD31 and PDGFR- $\beta$ staining. PDGFR- $\beta^{+}$murals cells are associated with CD $31^{+}$ECs in the stroma, myometrium and serosa. (E) CD31 and SMA staining. SMA labels glandular epithelium (g) and smooth muscle cells in the 
myometrium and serosa and is not associated with CD31 ${ }^{+}$ECs in the stroma. (F) FITC-dextran is detected throughout the endometrial stroma, in both small and large capillaries (F1, arrowheads), and myometrium. DAPI identifies all nuclei in IF images. Bar in $\mathrm{A}-\mathrm{E}=100 \mu \mathrm{m}$. Bar in $\mathrm{F}=500 \mu \mathrm{m}$. Bar in B1 $-\mathrm{F} 1=50 \mu \mathrm{m}$.

At E3.5 prior to embryo implantation, $\mathrm{CD} 31^{+} \mathrm{ECs}$ in the endometrial stroma, myometrium and serosa are closely associated with NG2 ${ }^{+}$and PDGFR- $\beta^{+}$mural cells (Fig. 1C, D, yellow signal). Magnified areas of the endometrial stroma are representative of the stroma, myometrium and serosa (Fig. 1, C1, D1). Endometrial $\mathrm{CD} 1^{+}$vessels are not associated with $\mathrm{SMA}^{+}$cells (Fig. 1E). SMA weakly labels glandular epithelia. SMA expression is seen throughout the myometrium and serosa, likely staining vSMCs, as well uterine smooth muscle cells (uSMCs) that also express NG2 and desmin (Fig. 1C, E, data not shown). Desmin expression is observed throughout the endometrium, stroma, myometrium and serosa and does not appear to be a specific marker of uterine vascular mural cells (data not shown).

The close association of NG2 ${ }^{+}$, PDGFR $-\beta^{+}$, and $\mathrm{SMA}^{-}$pericytes with $\mathrm{CD} 31^{+}$ECs suggests that these vessels are functional capillaries. Intravenous injection of FITC-conjugated dextran shows dextran in vascular structures throughout the pre-implantation endometrial stroma (Fig. 1F). We conclude that functional capillaries are present a day prior to embryo implantation. These capillaries are evident as pericyte-covered $\mathrm{CD} 31^{+}$vessels within the stroma.

\section{Characterization of blood vessels in the post-implantation murine uterus}

At E6.5 after embryo implantation, the decidua is rich with CD31 ${ }^{+}$blood vessels necessary to maintain pregnancy prior to placentation that begins at E7.5 (Fig. 2B-E). In the myometrium and inter-implantation sites, $\mathrm{NG}^{+}$cells are closely associated with $\mathrm{CD} 31^{+} \mathrm{ECs}$ (Fig. 2B , boxes, yellow signal). In the decidua, NG2 expression is abundant in the anti-mesometrial region, but few NG2 ${ }^{+}$mural cells are associated with $\mathrm{CD} 31$ ${ }^{+}$ECs (Fig. 2B , arrowheads in B1). A majority of PDGFR- $\beta^{+}$cells are associated with CD31 ${ }^{+}$ECs with the heaviest coverage in the vessels in the anti-mesometrial decidua, myometrium and serosa (Fig. 2C, yellow signal). In contrast, very few NG2 ${ }^{+}$and PDGFR- $\beta^{+}$mural cells are found in the mesometrial decidua. Desmin expression is observed throughout the E6.5 implantation site, in decidual cells and stromal cells and in myometrium (Fig. 2D). Similar to E3.5, SMA labels vSMC and uSMCs in the E6.5 myometrium (Fig. 2E). Taken together, $\mathrm{NG}^{+}$and PDGFR- $\beta^{+}$cells associated with $\mathrm{CD} 31^{+}$ECs represent pericytes that likely have an active role in decidual angiogenesis.

Fig. 2

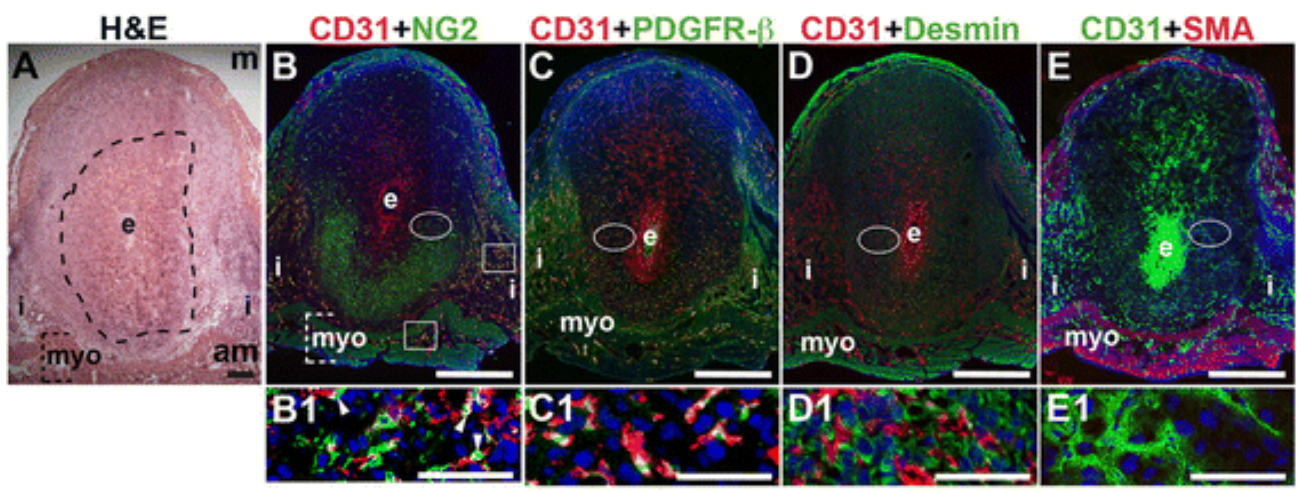

Characterization of endothelial cells and mural cells in the post-implantation uterus. H\&E and double staining IF of E6.5 uterine sections through implantation sites, showing inter-embryonic regions and central parts of the decidua. Ovals indicate areas of the uteri magnified (B1 - E1). (A) H\&E at E6.5 highlighting the embryo (e), inter-implantation sites (i), myometrium [dashed bracket (myo)], and decidua, which is between the embryo and dashed line. $(\mathrm{B}-\mathrm{E}) \mathrm{CD} 31^{+} \mathrm{ECs}$ are observed throughout the decidua, interimplantation sites, and myometrium. (B) CD31 and NG2 staining. $\mathrm{NG}^{+}$mural cells are associated with $\mathrm{CD} 31^{+} \mathrm{ECs}$ in the myometrium (boxes) and in the decidua (arrowheads in B1). $\mathrm{NG} 2^{+}$mural cells are abundant in the anti-mesometrial (am) decidua and sparse in the mesometrial (m) decidua. (C) CD31 and PDGFR $-\beta$ staining. PDGFR- $\beta^{+}$murals cells are associated with $\mathrm{CD} 31^{+}$ECs in the anti-mesomestrial decidua and myometrium. PDGFR $-\beta^{+}$mural cells are abundant in the anti-mesometrial decidua and sparse in the mesometrial decidua (D) CD31 and desmin staining. Desmin ${ }^{+}$cells are observed throughout the decidua and myometrium. (E) CD31 and SMA staining. SMA ${ }^{+}$smooth muscle cells are observed in the myometrium and are not associated with $\mathrm{CD} 31^{+}$decidual ECs. DAPI identifies all nuclei in IF images. Bar in $\mathrm{A}=100 \mu \mathrm{m}$. Bar in $\mathrm{B}-\mathrm{E}=500 \mu \mathrm{m}$. Bar in $\mathrm{B} 1-\mathrm{E} 1=50 \mu \mathrm{m}$. 
To determine the presence of functional decidual vessels, we performed FITC-conjugated $10 \mathrm{kDa}$ dextran studies in E6.5 females. FITC-dextran identifies patent capillaries within the mesometrial decidua running laterally from the inter-implantation sites to the embryo (Fig. 3D, D2 and D3). These mesometrial vessels appear to be leaky as areas of extravasation are readily observed. FITC-dextran extravasation is seen into blood filled sinusoids in the implantation crypt around the embryo (Fig. 3D, D1), where CD31 staining is also present (Fig. 3D, B1), and in the lateral vascular sinuses (Fig. 3D, D2 and D3). The distribution of FITCdextran suggests that functional, patent vessels as well as areas of increased vascular permeability are present in the mesometrial decidua, the site of placenta development.

Fig. 3

H\&E

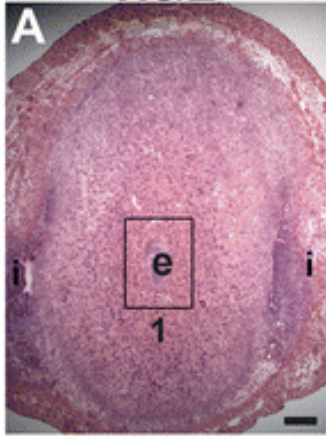

$H \& E$

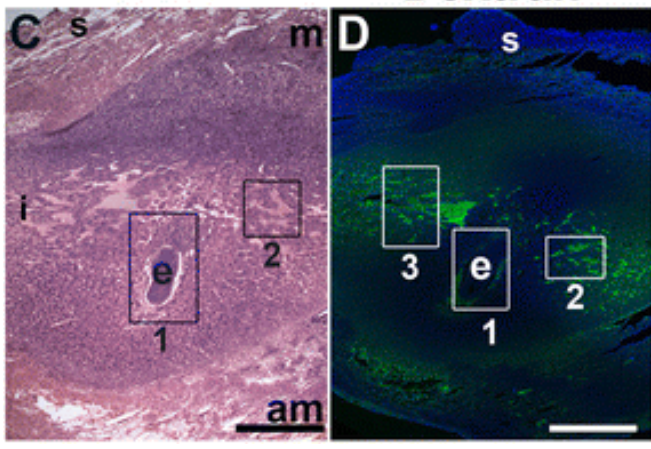

\section{CD31}

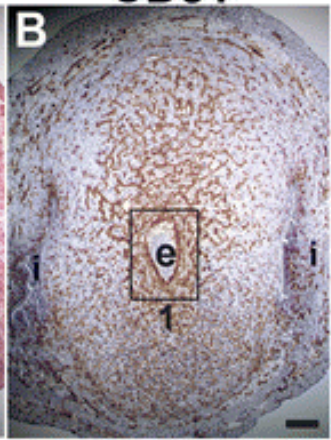

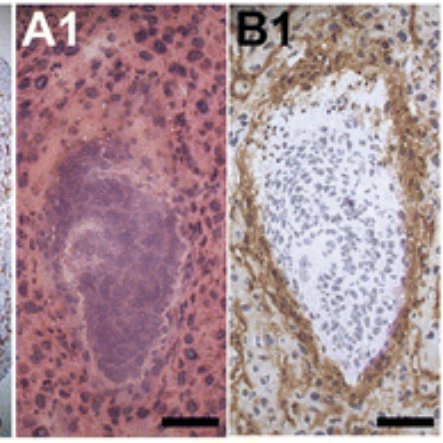

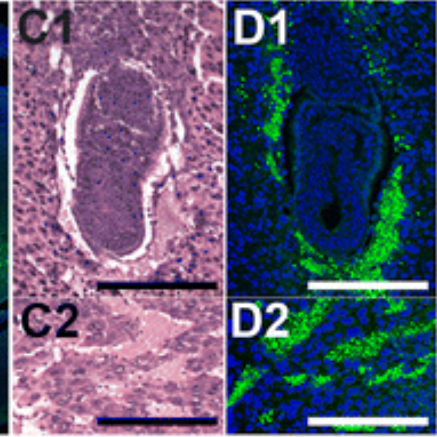

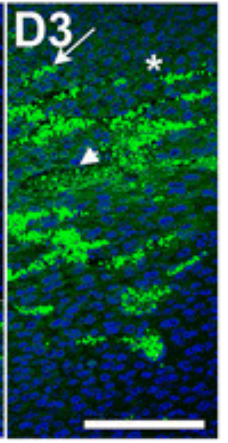

Distribution of endothelial cells and patent vessels identified by FITC-dextran in the post-implantation uterus. $\mathrm{H} \& \mathrm{E}, \mathrm{IHC}$ and fluorescently labeled dextran in E6.5 uterine sections. (A) H\&E at E6.5 highlighting the embryo (e) and inter-implantation sites (i). (B) CD31 ${ }^{+} \mathrm{ECs}$ are abundant in the decidua and myometrium. (C) H\&E at E6.5 highlighting the embryo surrounded by blood filled maternal sinusoids (box $1, \mathrm{C} 1$ ) and the blood filled lateral vascular sinuses in the mesometrial decidua (box 2, C2). (D) FITCdextran is detected in capillaries (D3, arrow) and has extravasated into sinusoids around the embryo (D1), lateral vascular sinuses in the mesometrial decidua (D2 and D3, arrowhead), and the stroma (D3, asterisk). DAPI identifies all nuclei in IF images. am, anti-mesometrial; $\mathrm{m}$, mesometrial; $\mathrm{s}$, serosa. Bar in A and B= $100 \mu \mathrm{m}$. Bar in $\mathrm{C}$ and $\mathrm{D}=500 \mu \mathrm{m}$. Bar in $\mathrm{A} 1$ and $\mathrm{B} 1, \mathrm{C} 1, \mathrm{C} 2, \mathrm{D} 1-\mathrm{D} 3=50 \mu \mathrm{m}$.

\section{Characterization of lymphatic vessels and macrophages in the peri-implantation uterus}

We used lymphatic endothelial hyaluronan receptor-1 (LYVE1) to detect lymphatic vessels [ 45] and CD11b [ 46, 47] and F4/80 [ 48- 50] to detect macrophages. At E3.5, LYVE1 lymphatic vessels are restricted to the myometrial and serosal layers of the uterus (Fig. 4B and C) and excluded from the endometrium and decidua. At E6.5, LYVE1 ${ }^{+}$cells are scattered throughout the decidua, without any apparent vascular pattern and likely do not represent lymphatic ECs (Fig. 4E, F), as LYVE1 is also expressed by a subset of macrophages [ 51]. F4/80 and LYVE1 double positive cells are observed in the myometrium at E6.5, but not at E3.5, suggesting that these cells are recruited subsequent to embryo implantation (Fig. 4F , arrowheads). The decidual LYVE1 ${ }^{+}$cells are neither CD11b, nor F4/80 positive indicating that they are not macrophages. 


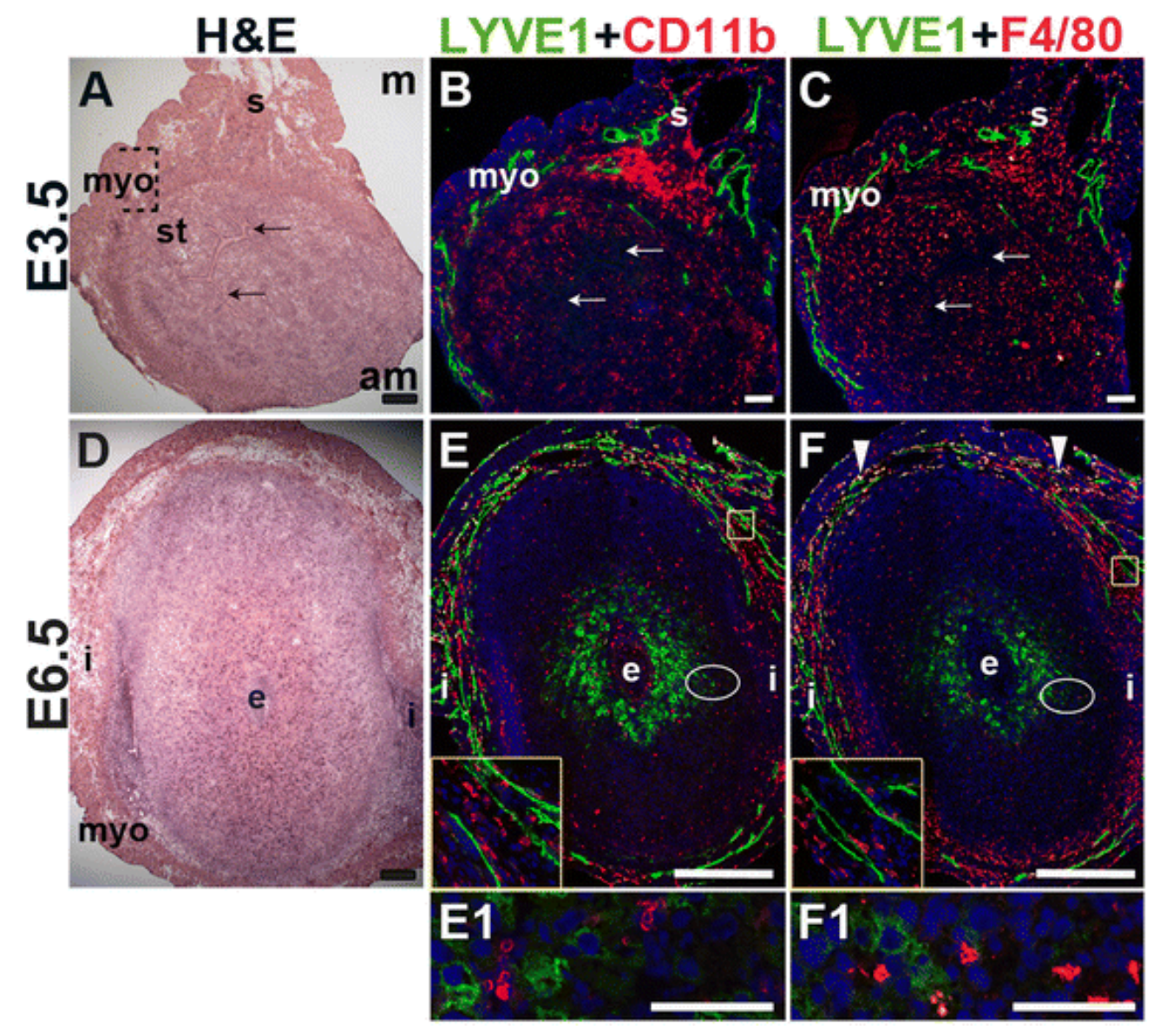

Characterization of lymphatic vessels and macrophages in the peri-implantation uterus. H\&E and double staining IF of E3.5 (A - C) and E6.5 (D - F) uterine sections. Ovals indicate areas of the uteri magnified (E1 and F1). (A) H\&E at E3.5 highlighting the luminal epithelium (arrows), inner circular and outer longitudinal myometrium [dashed bracket (myo)], endometrial stroma (st) and serosa (s). (B, C) LYVE1

${ }^{+}$lymphatics are observed throughout the myometrium and serosa, but are not detected in the endometrial

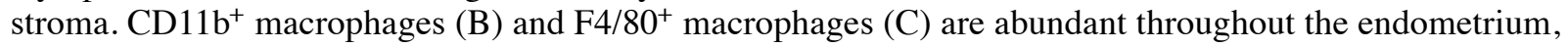
myometrium, and serosa, but their distribution patterns differ. (D) H\&E at E6.5 highlighting the embryo (e), inter-implantation sites (i) and myometrium (myo). (E, F) LYVE1 ${ }^{+}$lymphatics are observed throughout the myometrium at E6.5. The LYVE1 positive staining in the decidua does not have a vascular pattern (E1, $\mathrm{F} 1) . \mathrm{CD}_{1} 1 \mathrm{~b}^{+}$macrophages $(\mathrm{E})$ and $\mathrm{F} 4 / 80^{+}$macrophages $(\mathrm{F})$ are abundant throughout the myometrium and serosa, but scattered throughout the decidua at E6.5. LYVE1 ${ }^{+} \mathrm{F} 4 / 80^{+}$macrophages are detected in the myometrium at E6.5 (F, white arrowheads). DAPI identifies all nuclei in IF images. am, anti-mesometrial; $\mathrm{m}$-mesometrial. Bar in $\mathrm{A}-\mathrm{D}=100 \mu \mathrm{m}$. Bar in $\mathrm{E}$ and $\mathrm{F}=500 \mu \mathrm{m}$. Bar in $\mathrm{E} 1$ and $\mathrm{F} 1=50 \mu \mathrm{m}$.

$\mathrm{CD}_{11} \mathrm{~b}^{+}$macrophages and $\mathrm{F} 4 / 80^{+}$macrophages are abundant throughout the myometrium and serosa at E3.5 and E6.5 (Fig. 4). These CD11b cells may be undifferentiated monocytes, as well as neutrophils or dendritic cells that also express this marker. Macrophages are abundant in the endometrial stroma before implantation (Fig. 4B, C), while their density is reduced throughout the decidua after implantation (Fig. 4E, F). The staining patterns suggest that different populations of macrophages exist within the peri-implantation uterus: a $\mathrm{CD}_{11 b^{+}}$subset and a F4/80 ${ }^{+}$subset at both E3.5 and E6.5 and a LYVE1 ${ }^{+}$and F4/80 ${ }^{+}$double positive subset in the myometrium at E6.5.

\section{Notch1 expression in the peri-implantation uterus}

To define the expression of Notch1 in the peri-implantation uterus, we stained for Notch1 along with the EC marker, CD31, the pericyte markers, NG2 and PDGFR- $\beta$ or the macrophage marker, F4/80. At E3.5, Notch1 is expressed predominantly in endometrial CD $31^{+} \mathrm{ECs}$, while low levels of Notch 1 are detected in luminal and glandular epithelial cells (Fig. 5A-D). At E6.5, Notch1 is expressed in decidual CD31+ ECs (Fig. 5G) of perfused vessels (Additional file 1: Figure S1). NG2 ${ }^{+}$and PDGFR- $\beta^{+}$pericytes are found in close association with Notch $1^{+}$ECs at both time points, suggesting that these pericytes cover Notch $1^{+}$ECs in capillaries (Fig. $5 \mathrm{C}, \mathrm{D}, \mathrm{H}$, and I). At E6.5, NG2 ${ }^{+}$and PDGFR $-\beta^{+}$pericyte coverage of Notch $1^{+}$ECs is most complete in the anti-mesometrial decidua (Fig. 5H and I). F4/80 $0^{+}$macrophages are observed in between two Notch $1^{+}$ECs in the pre-implantation endometrial stroma (Fig. 5E, arrowheads). In the post-implantation decidua, F4/80 ${ }^{+}$macrophages are not associated with Notch $1^{+}$cells (Fig. 5F). In the peri-implantation uterus, Notch 1 is 
expressed in the decidual capillary endothelium that is covered with $\mathrm{NG}^{+}$and PDGFR- $\beta^{+}$pericytes. Prior to implantation, these Notch1 expressing capillaries make contact with $\mathrm{F} 4 / 80^{+}$macrophages in the endometrium. Notch1 labels neither vSMCs, nor uSMCs in the myometrium and serosa.

Fig. 5
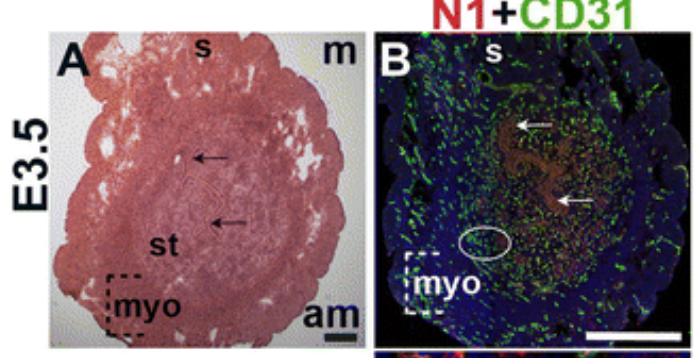

$\mathrm{N} 1+\mathrm{CD} 31$
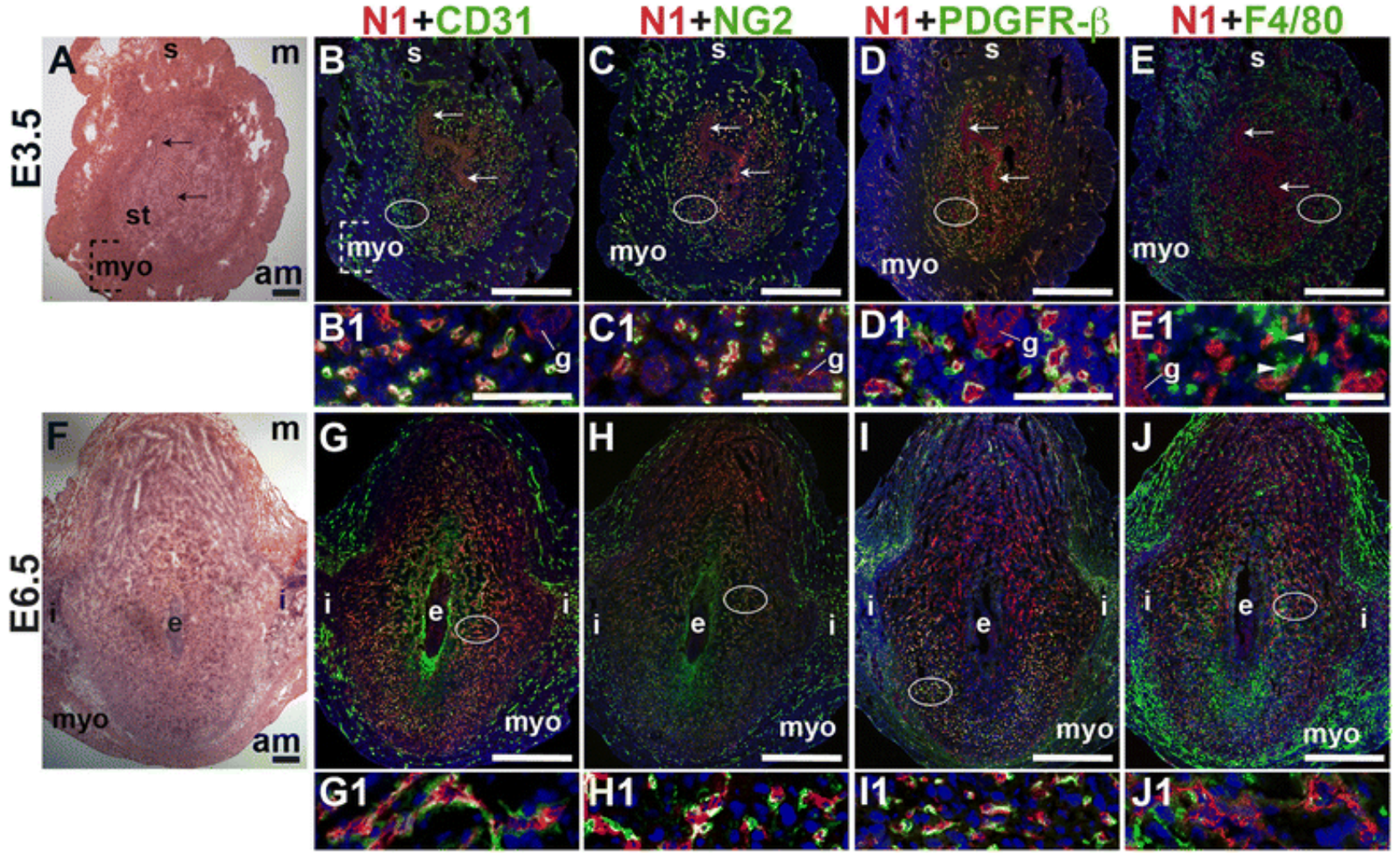

Notch1 (N1) expression in endothelial cells, mural cells and macrophages in the peri-implantation uterus. H\&E and double staining IF of E3.5 (A - E) and E6.5 (F - J) uterine sections. Ovals indicate areas of the uteri magnified (B1 - E1 and G1 - J1). (A) H\&E at E3.5 highlighting the luminal epithelium (arrows), inner circular and outer longitudinal myometrium [dashed bracket (myo)], endometrial stroma (st) and serosa $(\mathrm{s})$. (B - E) Notch $1^{+}$cells are observed throughout the endometrial stroma, myometrium and serosa at E3.5. Low levels of Notch1 are detected in the luminal (arrows) and glandular epithelium (g). (B)

Notch1 and CD31. Notch1 is expressed in CD31 $1^{+}$ECs. NG2 ${ }^{+}$mural cells (C) and PDGFR- $\beta^{+}$mural cells (D) are associated with Notch $1^{+}$cells in the stroma, myometrium, and serosa. (E) Notch1 and F4/80. F4/80 labels macrophages in stroma, myometrium and serosa. $\mathrm{F} 4 / 80^{+}$macrophages are adjacent to Notch $1^{+}$cells (arrowheads in E1). (F) H\&E at E6.5 highlighting the embryo (e), inter-implantation sites (i), and myometrium (myo). $(\mathrm{G}-\mathrm{J})$ Notch $1^{+}$cells are observed throughout the decidua and inter-implantation sites at E6.5. (G) Notch1 and CD31. Notch1 is expressed in CD31 $1^{+}$decidual ECs. (H) Notch1 and NG2. NG2 ${ }^{+}$mural cells are associated with Notch $1^{+}$cells in the decidua. (I) Notch 1 and PDFGR- $\beta$. PDGFR- $\beta^{+}$mural cells are associated with Notch $1^{+}$cells in the decidua. (J) Notch 1 and F4/80. F4/80 macrophages are not associated with Notch $1^{+}$cells in the decidua, myometrium and inter-implantation sites. DAPI identifies all nuclei in IF images. am, anti-mesometrial; $\mathrm{m}$, mesometrial. Bar in A and $\mathrm{F}=100 \mu \mathrm{m}$. Bar in $\mathrm{B}-\mathrm{E}$ and $\mathrm{G}-$ $\mathrm{J}=500 \mu \mathrm{m}$. Bar in B1 $-\mathrm{E} 1$ and $\mathrm{G} 1-\mathrm{J} 1=50 \mu \mathrm{m}$.

\section{Notch4 expression in the peri-implantation uterus}

To define the expression of Notch4, we stained for Notch4 and the EC marker, CD31, or the SMC marker, SMA. At E3.5, Notch4 is expressed in CD31 ${ }^{+}$ECs throughout the endometrium and in a subset of large vessels in the myometrium (Fig. 6B, box highlights myometrial vessel). Notch4 is not detected in cells that express SMA in the myometrium and serosa (Fig. 6C and F). During post-implantation at E6.5, endothelial Notch4 expression is strongest in the mesometrial decidua where the placenta will form (Fig. 6E). Notch4 ${ }^{+}$cells are also observed in the myometrium and do not express SMA (Fig. 6F). Notch4 is mainly expressed in CD31 ${ }^{+}$ECs at E3.5 and in decidual ECs at E6.5. Our data show Notch4 expression in both capillaries and larger vessels in the peri-implantation uterus. 


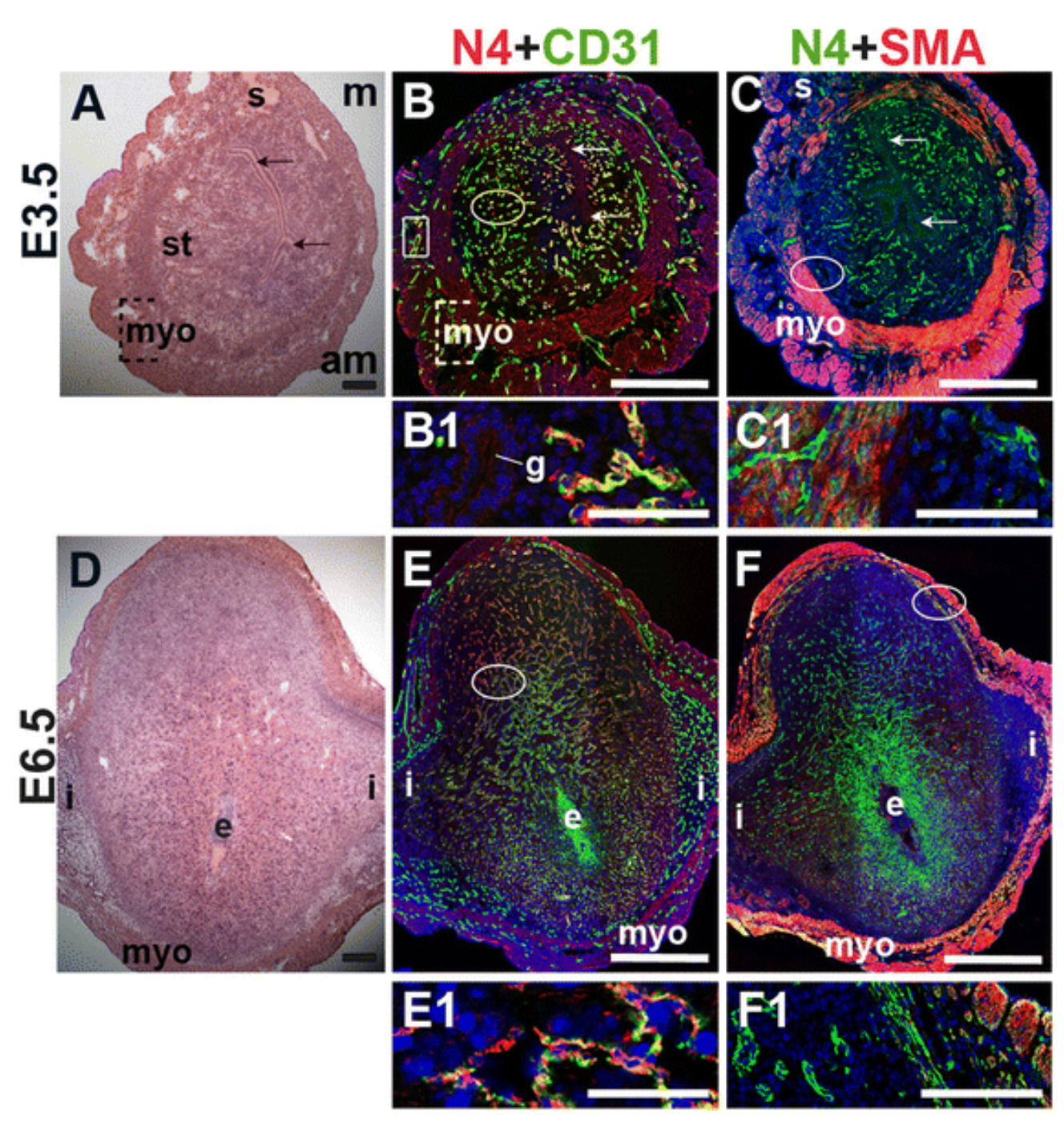

\begin{abstract}
Notch4 (N4) expression in endothelial cells and mural cells in the peri-implantation uterus. H\&E and double staining IF of E3.5 (A - C) and E6.5 (D - F) uterine sections. Ovals indicate areas of the uteri magnified (B1, C1, E1, F1). (A) H\&E at E3.5 highlighting the luminal epithelium (arrows), inner circular and outer longitudinal myometrium [dashed bracket (myo)], endometrial stroma (st) and serosa (s). (B, C) Notch $4^{+}$cells are observed throughout the stroma, myometrium and serosa. Low levels of Notch 4 are detected in the luminal (arrows) and glandular epithelium (g). (B) Notch4 and CD31. Notch4 is expressed in $\mathrm{CD} 31^{+}$ECs in the endometrium (oval) and myometrium (box). (C) Notch4 and SMA. SMA labels smooth muscle cells in the myometrium and serosa and is not associated with cells expressing Notch4. (D) H\&E at E6.5 highlighting the embryo (e), inter-implantation sites (i), and myometrium (myo). (E, F) Notch $4^{+}$cells are observed throughout the decidua and myometrium at E6.5. (E) Notch4 and CD31. Notch4 is expressed in CD31 $1^{+}$ECs in the decidua. (F) Notch4 and SMA. Notch4 is not associated with SMA ${ }^{+}$smooth muscle cells in the myometrium and serosa. DAPI identifies all nuclei in IF images. am, antimesometrial; $\mathrm{m}$, mesometrial. Bar in $\mathrm{A}$ and $\mathrm{D}=100 \mu \mathrm{m}$. Bar in $\mathrm{B}, \mathrm{C}, \mathrm{E}$, and $\mathrm{F}=500 \mu \mathrm{m}$. Bar in $\mathrm{B} 1, \mathrm{C} 1, \mathrm{E} 1$, and $\mathrm{F} 1=50 \mu \mathrm{m}$.
\end{abstract}

\title{
Notch2 and Notch3 are predominantly expressed in SMCs in the peri-implantation uterus
}

To determine Notch2 and Notch3 expression patterns, E3.5 and E6.5 uteri were stained for Notch2 or Notch3 and EC marker, CD31 or mural cell markers, PDGFR- $\beta$ and SMA. At E3.5, Notch2 expression is observed in a subset of CD31+ endometrial ECs (Fig. 7B , arrowhead). In contrast, Notch2 expression is not associated with CD31 $1^{+}$ECs in the E6.5 decidua (Fig. 7F). At both time points, Notch2 expression does not overlap with the vascular mural cell marker, PDGFR- $\beta$. In the myometrium, Notch2 is expressed in the SMA ${ }^{+}$uSMCs of the inner circular and outer longitudinal fibers (Fig. 7D and $\mathrm{H}$, yellow signal). The expression pattern of Notch2 in the decidua does not support a role for Notch2 in decidual angiogenesis. 


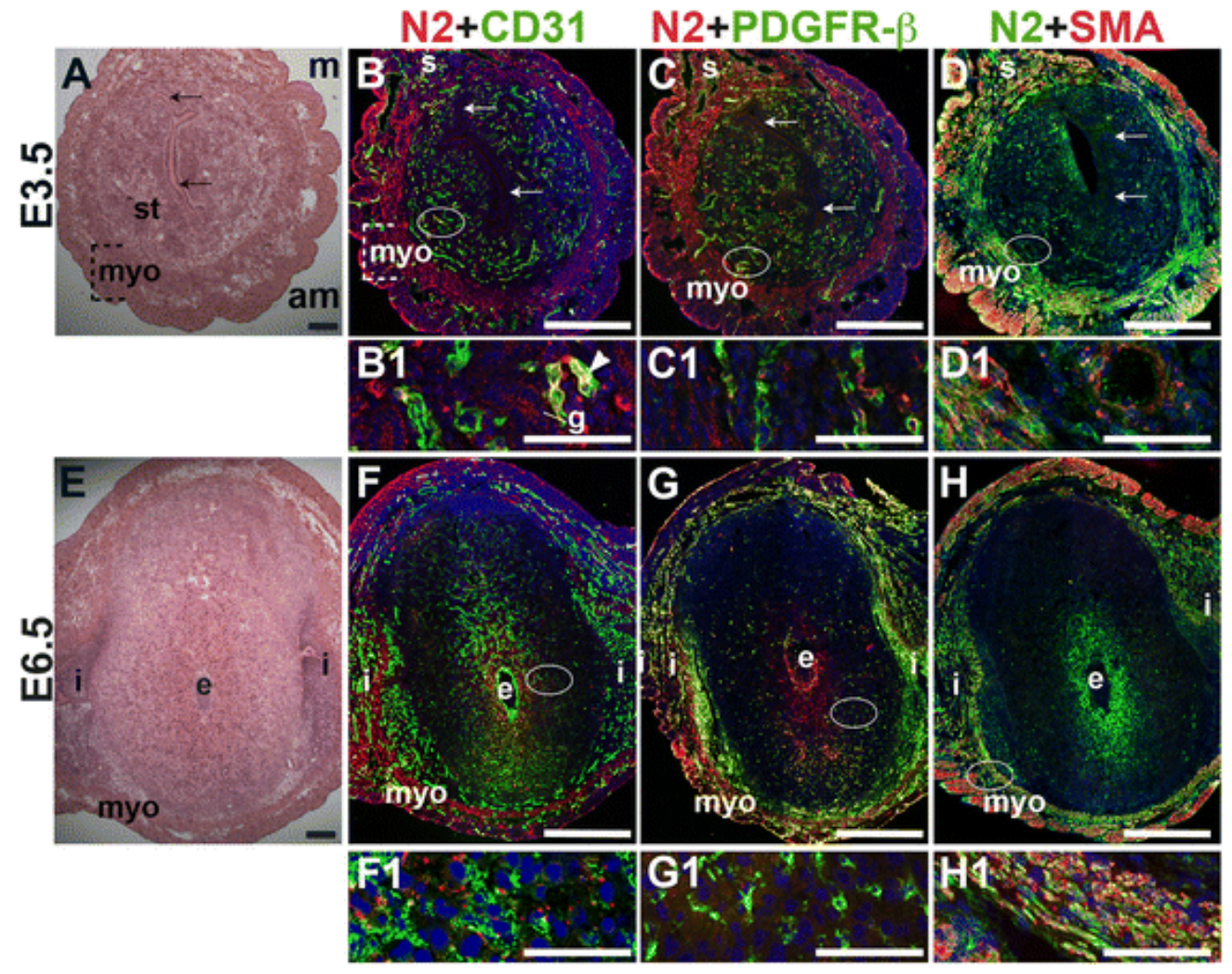

Location of Notch2 (N2) in relation to endothelial cells and mural cells in the peri-implantation uterus. $\mathrm{H} \& \mathrm{E}$ and double staining IF of E3.5 (A - D) and E6.5 (E - H) uterine sections. Ovals indicate areas of the uteri magnified (B1 - D1, F1 - H1). (A) H\&E at E3.5 highlighting the luminal epithelium (arrows), and myometrium (myo), and endometrial stroma (st). (B - D) Notch $2^{+}$cells are observed throughout the stroma, myometrium and serosa (s), with low levels of Notch2 in endometrial glands (g). (B) Notch2 and $\mathrm{CD} 31$. Notch $2^{+}$cells in association with $\mathrm{CD} 31^{+}$ECs are scattered sparsely throughout the endometrium (arrrowhead in B1) and serosa (s). (C) Notch2 and PDGFR- $\beta$. Notch2 is not associated with PDGFR- $\beta$ ${ }^{+}$mural cells in the stroma and myometrium. (D) Notch2 and SMA. SMA ${ }^{+}$smooth muscle cells are observed adjacent to Notch $2^{+}$cells in myometrium. Some uterine smooth muscle cells express both Notch2 and SMA. (E) H\&E at E6.5 highlighting the embryo (e), inter-implantation sites (i), and myometrium (myo). $(\mathrm{F}-\mathrm{H})$ Notch $2^{+}$cells are observed throughout the myometrium. (F) Notch2 and CD31. Notch2 is not expressed in CD31 ${ }^{+}$decidual vessels. (G) Notch2 and PDGFR- $\beta$. Notch2 is not associated with PDGFR- $\beta$ in the decidua or myometrium. (H) Notch2 and SMA staining. SMA ${ }^{+}$smooth muscle cells are observed adjacent to Notch $2^{+}$cells in myometrium. Some uSMCs express both Notch2 and SMA. DAPI identifies all nuclei in IF images. am, anti-mesometrial; $\mathrm{m}$, mesometrial. Bar in A and $\mathrm{E}=100 \mu \mathrm{m}$. Bar in B $-\mathrm{D}$ and $\mathrm{F}-\mathrm{H}=500 \mu \mathrm{m}$. Bar in $\mathrm{B} 1-\mathrm{D} 1$ and $\mathrm{F} 1-\mathrm{H} 1=50 \mu \mathrm{m}$.

Notch3 is not expressed by $\mathrm{CD} 31^{+}$ECs in the peri-implantation murine uterus (Fig. 8B and F). In the E3.5 endometrium, Notch3 is expressed in PDGFR- $\beta^{+}$pericytes (arrowheads in C1) and in luminal and glandular epithelium, where it is localized apically (Fig. 8B-D). At both pre- and post-implantation time points, Notch3 is strongly expressed in uSMCs throughout the myometrium, as well as vSMCs surrounding large arteries (Fig. 8D and H). Notch3 is restricted to the vascular mural cells and myometrial SMCs in the periimplantation murine uterus. As in other tissues where Notch3 has been examined [ 34, 52], Notch3 is a smooth muscle cell-specific protein in the pre- and post-implantation uterus.

Fig. 8 


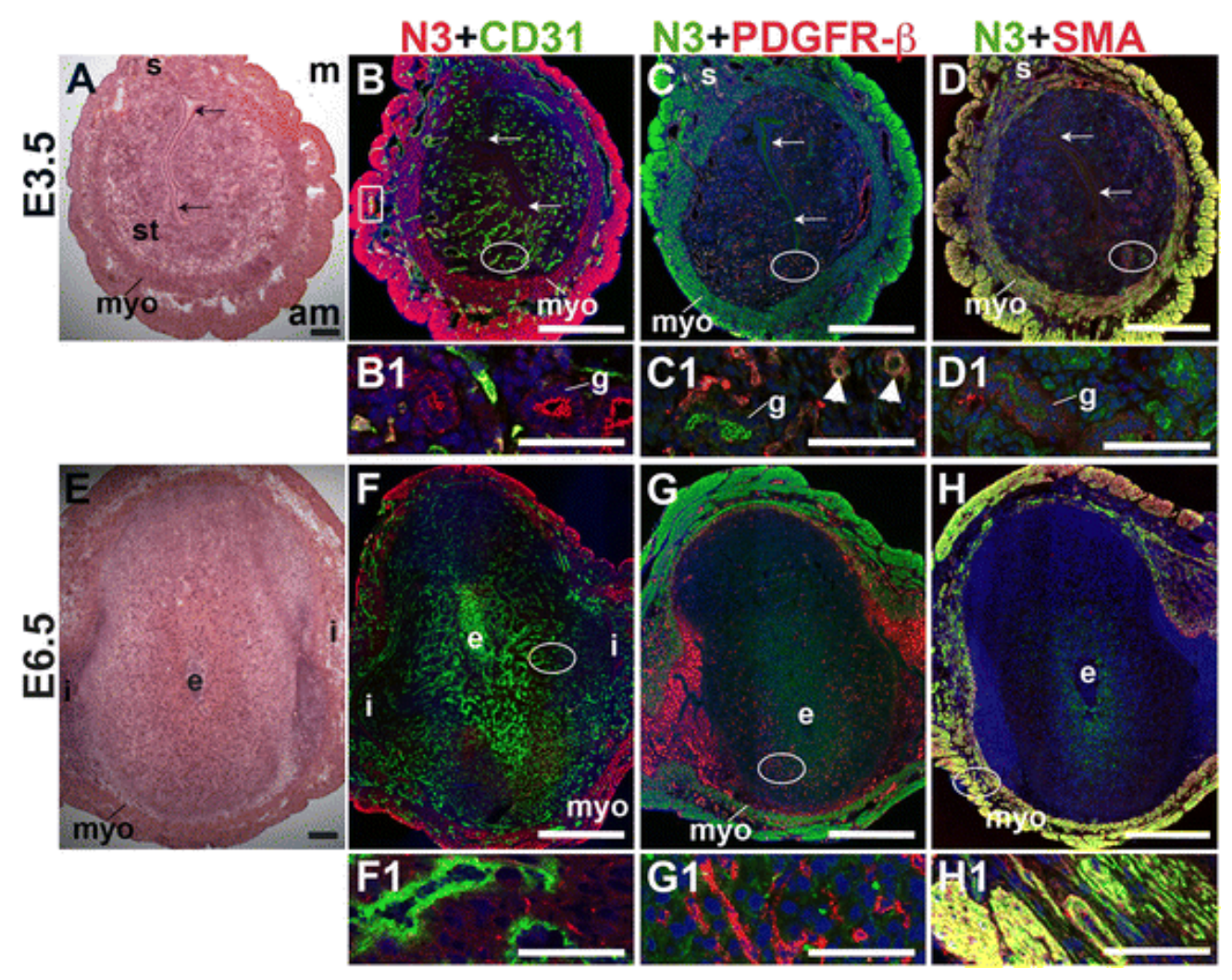

Location of Notch3 (N3) in relation to endothelial cells and mural cells in the peri-implantation uterus. $\mathrm{H} \& \mathrm{E}$ and double staining IF of E3.5 (A - D) and E6.5 (E - H) uterine sections. Ovals indicate areas of the uteri magnified (B1 - D1, F1 - H1). (A) H\&E at E3.5 highlighting the luminal epithelium (arrows), inner circular and outer longitudinal myometrium [dashed bracket (myo)], endometrial stroma (st) and serosa (s). $(\mathrm{B}-\mathrm{D})$ Notch $3^{+}$cells are observed throughout the myometrium and serosa and in endometrial glands $(\mathrm{g})$. (B) Notch3 and CD31. Notch3 is not expressed in CD31 $1^{+}$ECs. (C) Notch3 and PDGFR- $\beta$. Notch3 is expressed in PDGFR- $\beta^{+}$mural cells in the endometrial stroma (arrowheads in C1). (D) Notch3 and SMA. Notch3 and SMA staining overlaps in the myometrium and serosa. (E) H\&E at E6.5 highlighting the embryo (e), inter-implantation sites (i), and myometrium (myo). $(\mathrm{F}-\mathrm{H})$ Notch $3^{+}$cells are observed throughout the myometrium. (F) Notch3 and CD31. Notch3 is not expressed in CD31 $1^{+}$ECs. (G) Notch3 and PDGFR- $\beta$. Notch 3 is not associated with PDGFR- $\beta$ in the decidua or myometrium. (H) Notch 3 and SMA. Notch3 and SMA staining overlaps in the myometrium. DAPI identifies all nuclei in IF images. am, anti-mesometrial; $\mathrm{m}$, mesometrial. Bar in $\mathrm{A}$ and $\mathrm{E}=100 \mu \mathrm{m}$. Bar in $\mathrm{B}-\mathrm{D}$ and $\mathrm{F}-\mathrm{H}=500 \mu \mathrm{m}$. Bar in $\mathrm{B} 1-$ $\mathrm{D} 1$ and $\mathrm{F} 1-\mathrm{H} 1=50 \mu \mathrm{m}$.

\section{Angiogenic Notch ligand expression in the peri-implantation uterus}

E3.5 and E6.5 uteri were stained for the angiogenic Notch ligands, D114 and Jag1 and either the EC marker, CD31 or the pericyte markers, NG2 and PDGFR- $\beta$. In the E3.5 pre-implantation uterus, Dll4 and Jag 1 are expressed in endometrial ECs (Figs. 9B and 10B). Dl14 ${ }^{+}$cells in the E3.5 endometrium are associated with $\mathrm{NG} 2^{+}$and PDGFR- $\beta^{+}$pericytes (Fig. 9C, D) $\mathrm{Jag} 1^{+}$is expressed on NG2${ }^{+}$and PDGFR- $\beta^{+}$pericytes (Fig. $10 \mathrm{C}, \mathrm{D}$, arrowheads highlight continuous yellow signal). In the E6.5 post-implantation decidua, most Dll4 ${ }^{+}$ECs are observed in the anti-mesometrial region (Fig. 9F). Whereas Dll4 is primarily expressed in small decidual capillaries, newly formed during decidual angiogenesis (Fig. 9), Jag1 is expressed in resident spiral arteries in the mesometrial decidua (Fig. 10F, box). At E6.5, NG2 $2^{+}$and PDGFR- $\beta^{+}$pericytes are still associated with Dll4 ${ }^{+}$and Jag1 ${ }^{+}$cells (Figs. 9G, H and 10G, H). The overlap of Jag1 and NG2 demonstrates that a subset of pericytes express Jag1 (Fig. 10G, arrowhead in G1). The different distribution of Jag $1^{+}$and Dl14 ${ }^{+}$cells suggests that Jag1 and Dll4 function in distinct populations of decidual ECs.

Fig. 9 


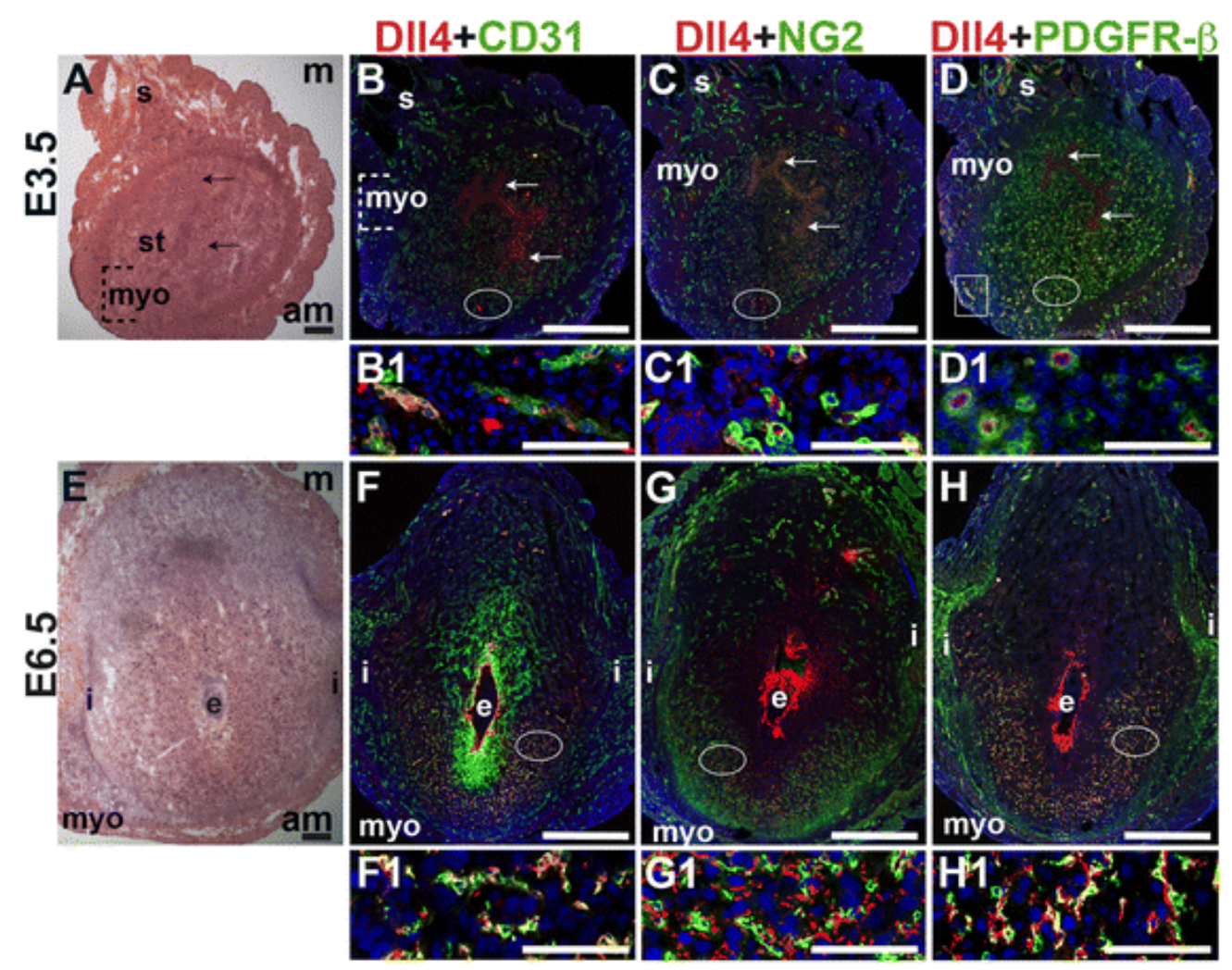

Expression of Notch ligand, Dll4 in relation to endothelial cells and mural cells in the peri-implantation uterus. H\&E and double staining IF of E3.5 (A - D) and E6.5 (E - H) uterine sections. Ovals indicate areas of the uteri magnified (B1 - D1, F1 - H1). (A) H\&E at E3.5 highlighting the luminal epithelium (arrows), inner circular and outer longitudinal myometrium [dashed bracket (myo)], endometrial stroma (st) and serosa (s). (B - D) Dll4 ${ }^{+}$cells are scattered throughout the stroma, myometrium (box) and serosa. (B) Dll4 and CD31. Dll4 is expressed in $\mathrm{CD} 1^{+} \mathrm{ECs}$ in the endometrial stroma. (C) Dll4 and NG2. NG2 ${ }^{+}$mural cells are observed adjacent to the Dll4 ${ }^{+}$cells in the stroma. (D) Dll4 and PDGFR- $\beta$. PDGFR- $\beta^{+}$mural cells surround Dll4 ${ }^{+}$stromal cells. (E) H\&E at E6.5 highlighting the embryo (e), inter-implantation sites (i), and myometrium (myo). $(\mathrm{F}-\mathrm{H})$ At E6.5, Dll4 ${ }^{+}$cells are observed throughout the decidua, with most Dll4 expression in the anti-mesometrial decidua. (F) Dll4 and CD31. D114 is expressed in CD31 ${ }^{+}$decidual ECs. (G) Dll4 and NG2. NG2 ${ }^{+}$mural cells are adjacent to Dll4 ${ }^{+}$decidual cells in the anti-mesometrium. (H) Dll4 and PDGFR- $\beta$. PDGFR- $\beta^{+}$mural cells are adjacent to Dll4 ${ }^{+}$decidual cells in the anti-mesometrium. DAPI identifies all nuclei in IF images. Bar in $\mathrm{A}$ and $\mathrm{E}=100 \mu \mathrm{m}$. Bar in $\mathrm{B}-\mathrm{D}$ and $\mathrm{F}-\mathrm{H}=500 \mu \mathrm{m}$. Bar in $\mathrm{B} 1-$ $\mathrm{D} 1$ and $\mathrm{F} 1-\mathrm{H} 1=50 \mu \mathrm{m}$.

Fig. 10 


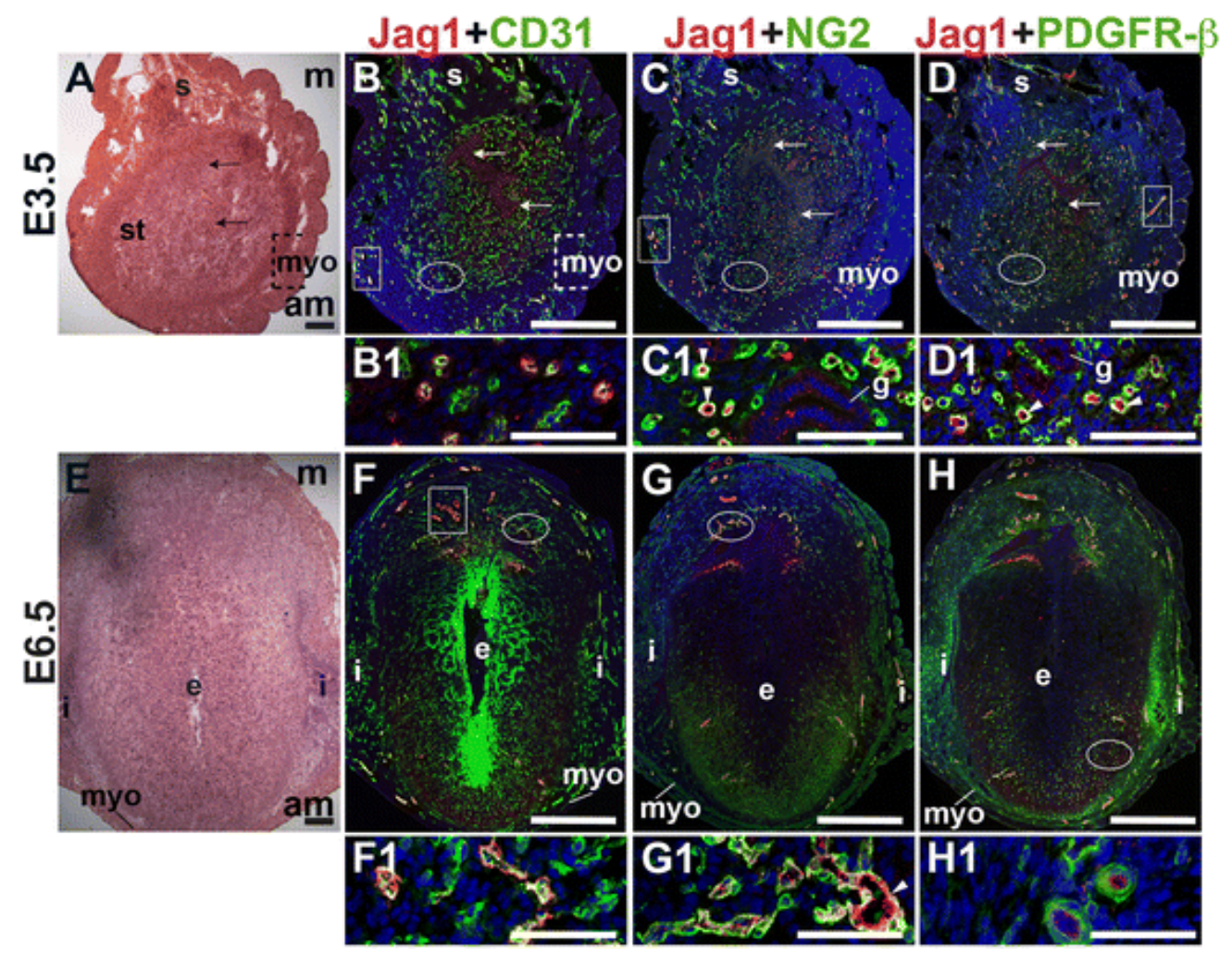

Expression of Notch ligand, Jagged1 (Jag1) in relation to endothelial cells and mural cells in the periimplantation uterus. H\&E and double staining IF of E3.5 (A - D) and E6.5 (E - H) uterine sections. Ovals indicate areas of the uteri magnified (B1 - D1, F1 - H1). (A) H\&E at E3.5 highlighting the luminal epithelium (arrows), inner circular and outer longitudinal myometrium [dashed bracket (myo)], endometrial stroma (st) and serosa (s). (B - D) Jag $1^{+}$cells are observed throughout the endometrial stroma and in the myometrium (boxes). (B) Jag1 and CD31. Jag1 is expressed in $\mathrm{CD} 31^{+} \mathrm{ECs}$ in the stroma and myometrium. (C) Jag1 and NG2. Jag1 is expressed on a subset of $\mathrm{NG} 2^{+}$mural cells in the stroma (arrowheads in C1). (D) Jag 1 and PDGFR- $\beta$. Jag 1 is expressed on a subset of PDGFR $-\beta^{+}$mural cells in the stroma (arrowheads in D1). (E) H\&E at E6.5 highlighting the embryo (e), inter-implantation sites (i), and myometrium (myo). (F$\mathrm{H})$ At E6.5, $\mathrm{Jag} 1^{+}$cells are observed in decidua and myometrium. (F) Jag 1 and CD31. Jag1 is expressed in $\mathrm{CD} 31^{+}$ECs of spiral arteries (box) in the mesometrial decidua and in large vessels in the anti-mesometrial decidua and myometrium. (G) Jag1 and NG2 staining. Jag1 is expressed on a subset of NG2 $2^{+}$mural cells in the mesometrial decidua (arrowhead in G1). (H) Jag1 and PDGFR- $\beta$. PDGFR- $\beta^{+}$mural cells surround Jag1 ${ }^{+}$cells in the decidua. DAPI identifies all nuclei in IF images. am, anti-mesometrial; $\mathrm{m}$, mesometrial. Bar in $\mathrm{A}$ and $\mathrm{E}=100 \mu \mathrm{m}$. Bar in $\mathrm{B}-\mathrm{D}$ and $\mathrm{F}-\mathrm{H}=500 \mu \mathrm{m}$. Bar in $\mathrm{B} 1-\mathrm{D} 1$ and $\mathrm{F} 1-\mathrm{H} 1=50 \mu \mathrm{m}$.

\section{Notch activity in ECs and pericytes in the peri-implantation uterus}

To determine Notch activity in the peri-implantation uterus, female $C B F: H 2 B$-Venus Notch reporter mice were mated to wild-type males. YFP expression was used to determine Notch signaling activity in CD31 ${ }^{+}$decidual ECs and PDGFR $-\beta^{+}$pericytes. At E3.5, Notch activity is observed in CD31 $1^{+}$ECs in the endometrium and myometrium (Fig. 11B , B1), in luminal and glandular epithelial cells (Fig. 11B and C, arrowheads), and in a subset of PDGFR- $\beta^{+}$pericytes (Fig. $11 \mathrm{C}, \mathrm{C} 1$ ). At E6.5, the $H 2 B$-Venus transgene is expressed in CD31 ${ }^{+}$ECs of decidual capillaries (Fig. 11E, E1), CD31 ${ }^{+}$ECs of myometrial vessels (Fig. 11E) and in a subset of PDGFR- $\beta^{+}$pericytes in the anti-mesometrial decidua (Fig. $11 \mathrm{~F}, \mathrm{~F} 1$ ). Thus, Notch activity is observed in ECs and pericytes in the peri-implantation uterus.

Fig. 11 

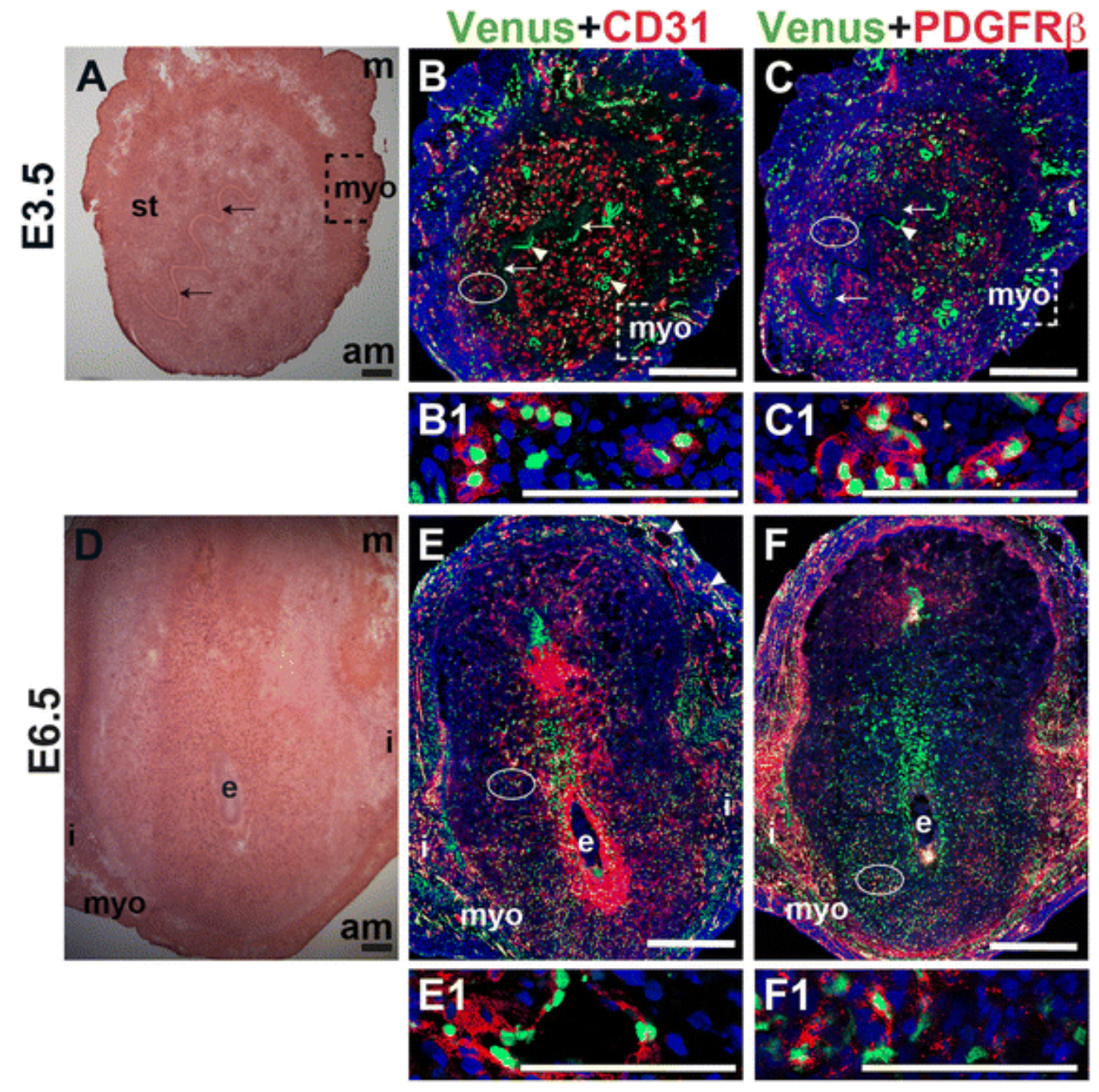

Notch activity in endothelial cells and mural cells in the peri-implantation uterus. (A) H\&E at E3.5 highlighting the luminal epithelium (arrows), inner circular and outer longitudinal myometrium [dashed bracket (myo)] and endometrial stroma (st). (B, C) IF of sections through the uterus of CBF:H2B-Venus Notch reporter mice enabled assessment of Notch activity at E3.5. Ovals indicate areas of the uteri magnified $(\mathrm{B} 1, \mathrm{C} 1)$. (B) Notch activity was observed in CD31+ ECs (red) in the stroma (B1), myometrium, and glandular epithelium (arrowheads). (C) Notch activity was observed in PDGFR- $\beta^{+}$mural cells in the stroma (C1) and myometrium. (D) H\&E at E6.5 highlighting the embryo (e), inter-implantation sites (i), and myometrium (myo). (E, F) IF of sections through implantation sites of female $C B F: H 2 B$-Venus Notch reporter mice at E6.5. Ovals indicate areas of the uteri magnified (E1, F1). (E) Notch activity was observed in $\mathrm{CD} 31^{+}$ECs of decidual capillaries (E1) and myometrial vessels. (F) Notch activity was observed in PDGFR- $\beta^{+}$mural cells in the anti-mesometrial decidua. DAPI identifies all nuclei in IF images. am, antimesometrial; $\mathrm{m}$, mesometrial. Bar in $\mathrm{A}$ and $\mathrm{D}=100 \mu \mathrm{m}$. Bar in $\mathrm{B}, \mathrm{C}, \mathrm{E}$, and $\mathrm{F}=500 \mu \mathrm{m}$. Bar in $\mathrm{B} 1, \mathrm{C} 1, \mathrm{E} 1$, and $\mathrm{F} 1=100 \mu \mathrm{m}$.

We assessed the expression of Hey2, a downstream effector of Notch signaling, in CD $31^{+}$ECs and SMA ${ }^{+}$SMCs in the peri-implantation uterus. Hey2 is not expressed by CD $31^{+}$ECs in the peri-implantation murine uterus (Fig. 12B and E). At both pre- and post-implantation time points, Hey2 is strongly expressed in uSMCs throughout the myometrium (Fig. 12C and F), as well as vSMCs surrounding large arteries (Fig. $12 \mathrm{C}, \mathrm{C} 1$, arrowhead).

Fig. 12 


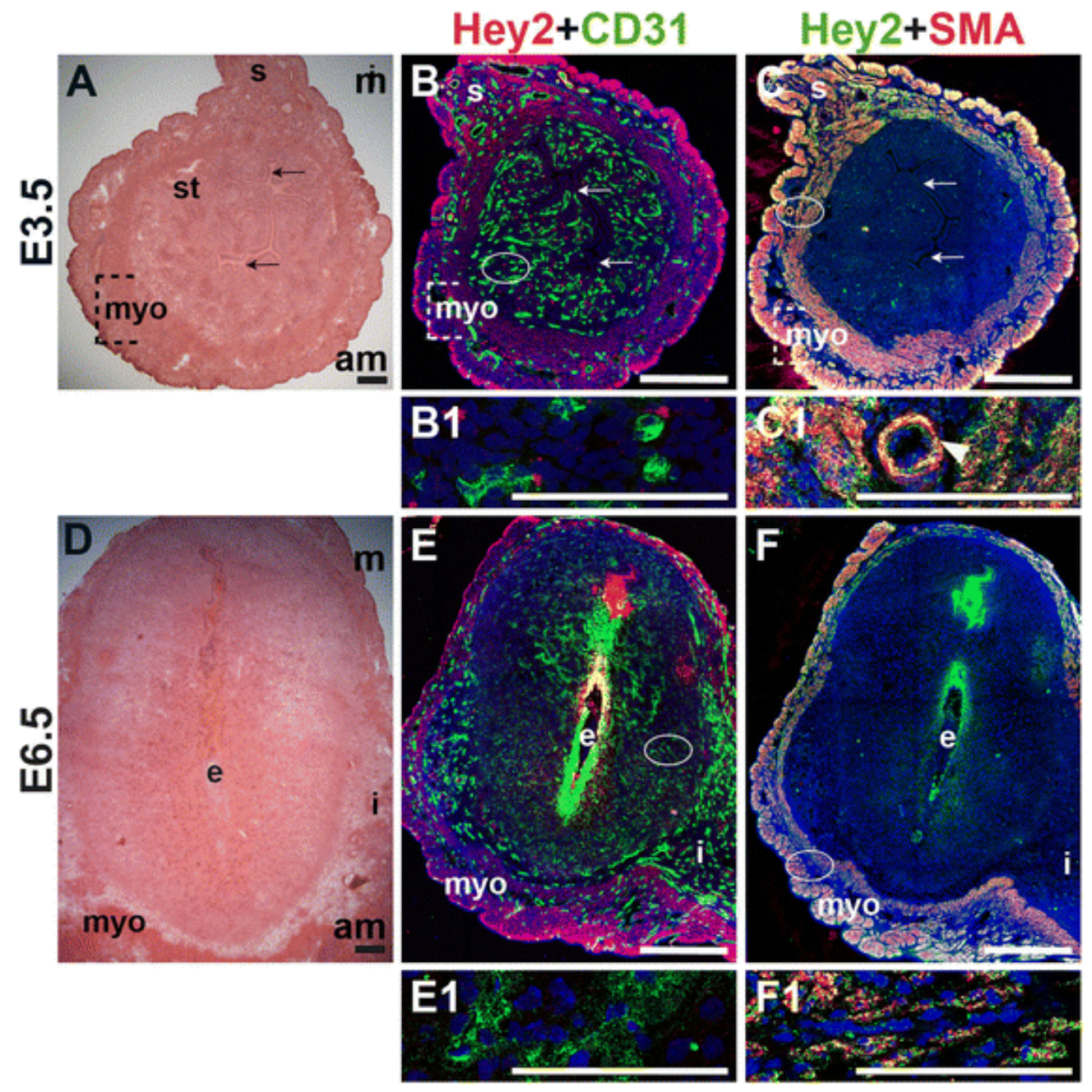

Expression of Notch effector protein, Hey2, in relation to endothelial cells and mural cells in the periimplantation uterus. H\&E and double staining IF of E3.5 (A - C) and E6.5 (D - F) uterine sections. Ovals indicate areas of the uteri magnified (B1, C1, E1 and F1). (A) H\&E at E3.5 highlighting the luminal epithelium (arrows), inner circular and outer longitudinal myometrium [dashed bracket (myo)], endometrial stroma (st) and serosa (s). (B, C) Hey $2^{+}$cells are observed throughout the myometrium and serosa. (B) Hey2 and CD31. Hey2 is not expressed in CD31 ${ }^{+}$ECs (B1). (C) Hey2 and SMA. Hey2 and SMA staining overlaps in the myometrium and serosa (C1). (D) H\&E at E6.5 highlighting the embryo (e), interimplantation sites (i), and myometrium (myo). (E, F) Hey $2^{+}$cells are observed throughout the myometrium. (E) Hey2 and CD31. Hey2 is not expressed in CD31 ${ }^{+}$ECs of decidual capillaries (E1). (F) Hey2 and SMA. Hey2 and SMA staining overlaps in the myometrium (F1). DAPI identifies all nuclei in IF images. am, antimesometrial; $\mathrm{m}$, mesometrial. Bar in A and D =100 $\mu \mathrm{m}$. Bar in $\mathrm{B}, \mathrm{C}, \mathrm{E}$, and $\mathrm{F}=500 \mu \mathrm{m}$. Bar in B1, C1, E1 and $\mathrm{F} 1=100 \mu \mathrm{m}$.

\section{Discussion}

Transformation of the pre-implantation E3.5 uterine endometrium to the post-implantation E6.5 uterine decidua requires angiogenesis and vascular remodeling to increase vascular permeability, and immune/inflammatory changes. This vascularization process assures successful embryo implantation and placenta formation [ 1,2]. Herein we show that prior to implantation, most vessels in the uterine endometrium are capillaries, defined as CD $31^{+}$ECs covered by NG2 ${ }^{+} /$PDGFR- $\beta^{+}$pericytes and lacking SMA expression. Macrophages are abundant throughout the endometrium, myometrium and serosa, whereas lymphatic vessels are restricted to the myometrium and serosa. After implantation, we found patent vessels lateral to the embryo running between the inter-implantation sites and the embryo. NG2 $2^{+}$and PDGFR- $\beta^{+}$pericytes are most abundant on newly formed decidual capillaries in the anti-mesometrial decidua. It is plausible that vessels in the mesometrial decidua, the site of vascular remodeling during placenta formation, may not require extensive pericyte coverage. Alternatively, a different population of pericytes, that does not express NG2, but may express desmin, could support the mesometrial vessels that do not express NG2. However, desmin is also expressed in the stromal cells and decidual cells and thus it is not possible to discriminate between desmin + pericytes and stromal cells. 
We hypothesized that Notch proteins and ligands would be differentially expressed in the vasculature and vascular associated mural cells of the pre-implantation uterus and post-implantation uterine decidua, reflecting their possible functions during decidualization. Prior to implantation, Notch1, Notch2 and Notch4 are expressed in the ECs and Notch3 is expressed in pericytes (Table 2). Notch1 EC expression is observed in the perfused capillaries containing FITC-labeled dextran. The Notch ligands, Dll4 and Jag1 are expressed in a subset of ECs, while Jag1 expression is observed in a subset of pericytes (Table 2). These Notch proteins and ligands are thus associated with pre-implantation endometrial capillaries. After implantation, we find Notch1, Notch4, Dl14, and Jag1 expression in decidual ECs and Jag1 expression in a subset of pericytes (Table 2). We observe EC Dll4 in the angiogenic vessels of the decidua (Table 2), consistent with the role of Dll4 in newly forming sprouts during angiogenesis [ 37]. Notch2, Notch3 and Notch4 are expressed in the peri-implantation myometrium. These data provide an essential foundation for conducting mechanistic studies to define the roles of individual Notch family members in decidual angiogenesis and placentation.

\section{Table 2}

Summary of Notch activity and expression in the peri-implantation mouse uterus

\begin{tabular}{|c|c|c|c|c|c|c|c|c|}
\hline & & $\begin{array}{c}\text { Notch } \\
\text { signaling }\end{array}$ & Notch1 & Notch2 & Notch3 & Notch4 & Dll4 & Jag1 \\
\hline \multirow[t]{5}{*}{$\begin{array}{l}\text { E3.5 Pre- } \\
\text { implantation }\end{array}$} & & & & & & & & \\
\hline & $\begin{array}{l}\text { Endothelial } \\
\text { cells }\end{array}$ & $\mathrm{X}$ & $\mathrm{X}$ & $\mathrm{X}$ & & $X$ & $X$ & \\
\hline & Pericytes & $X$ & & & $X$ & & & $X$ \\
\hline & vSMCs & $X$ & & & $\mathrm{X}$ & & & \\
\hline & uSMCs & $\mathrm{X}$ & & $X$ & $X$ & & & \\
\hline \multirow{4}{*}{$\begin{array}{l}\text { E6.5 Post- } \\
\text { implantation }\end{array}$} & $\begin{array}{l}\text { Endothelial } \\
\text { cells }\end{array}$ & $\mathrm{X}$ & $\mathrm{X}$ & & & $X$ & $X$ & $X$ \\
\hline & Pericytes & $\mathrm{X}$ & & & & & & $X$ \\
\hline & vSMCs & $\mathrm{X}$ & & & $\mathrm{X}$ & & & \\
\hline & uSMCs & $X$ & & $X$ & $X$ & & & \\
\hline
\end{tabular}

uSMCs, uterine smooth muscle cells; vSMCs, vascular smooth muscle cells

Notch1 and Notch1/Notch4 mutant embryos have lethal angiogenic defects, with more severe phenotypes in Notch1/Notch4 double mutants [ 30]. Endothelium-specific activation of Notch1 or Notch4 and disruption of Notch signaling within the vasculature [ $24,31,32]$ also results in embryonic lethality by mid-gestation with defects in fetal angiogenesis. These mutants reveal the importance of Notch1 and Notch4 in formation of fetalderived embryonic and placental components. Notch1 has been previously been reported to be expressed in mouse and primate maternal uterine stromal cells during decidualization [ 53, 54]. The contribution of Notch1 and Notch4 signaling to maternal-derived placental vascular components or the pre-placental decidual vasculature has not as yet been investigated. We show that Notch1 is expressed in capillaries and excluded from macrophages in the peri-implantation uterus. Notch $1^{+} \mathrm{ECs}$ are uniformly distributed throughout the decidua, while Notch4 expression in ECs is more abundant in the mesometrial decidua. The partially overlapping expression patterns for Notch1 and Notch4 suggests that Notch1 and Notch4 may have some functionally redundancy in decidual angiogenesis. Further, active Notch signaling in both decidual ECs, which express Notch1 and Notch4, and pericytes suggests that the Notch pathway has a fundamental role in decidual angiogenesis.

Homozygous null mutants of Jagl and Dll4 die during embryogenesis due to vascular defects [ 26, 55- 58]. The umbilical artery and placental blood vessels are decreased in size in Dll4 heterozygous mutant embryos [ 59]. The requirement for Dll4-mediated signaling in decidual angiogenesis was recently investigated [ 37]. Peri-implantation administration of a D114 blocking antibody resulted in increased, but non-productive decidual angiogenesis that compromised pregnancies by E9.5, with very few embryos surviving to E13.5 [ 37]. In this model, Dll4-mediated signaling was blocked during decidualization, however it is unclear whether subsequent placentation was affected, leading to the abnormal embryonic development observed. Our finding of Dll4 in capillaries in the anti-mesometrial uterine decidua supports the finding that Dll4 signaling is required for proper decidual angiogenesis. Jag1 is expressed in decidual ECs of maternal spiral arteries and in pericytes. The different expression patterns of Dll4 and Jag1 in the decidual vasculature suggest unique functions for these Notch ligands. 
During pregnancy, the lymphatic vasculature is believed to play a role in regulating the fluid balance between the maternal and fetal compartments and in maintaining maternal tolerance of the semi-allogeneic fetus [ 45 , $60,61]$. There is general agreement that the myometrium and serosa of both humans and mice contain lymphatic vessels $[60,62,63]$. Whereas $\mathrm{LYVE1}^{+}$lymphatics have not been detected in the endometrium of the non-pregnant human uterus $[60,64]$, podoplanin ${ }^{+}$lymphatics are abundant in the endometrium basalis, the region directly adjacent to the myometrium and sparse in the endometrium functionalis, the region that is shed during menses [ 63]. LYVE1 ${ }^{+}$lymphatics are prominent in the decidua during all trimesters of human pregnancy, but have not been detected in the murine decidua [ 60]. Similarly, we do not observe LYVE1 ${ }^{+}$lymphatic vessels in the peri-implantation murine decidua. Further investigation with additional lymphatic markers is necessary to confirm the difference between humans and mice.

Pregnancy is associated with an influx of macrophages into the uterus [ 65,66$]$. Macrophages are proposed to function in coordinating the maternal immune response, in apoptosis and tissue remodeling at the maternalfetal interface, as well as in promoting angiogenesis [ 67,68]. Macrophages are recruited into the endometrium during the peri-implantation period such that decidual macrophages are the second most abundant immune cell population at the implantation site, comprising 20-30\% of immune cells in the uterine decidua $[69,70]$. Whereas CD11b is expressed by myeloid cells other than macrophages, F4/80 is expressed by mature macrophages [ 46,50$]$. F4/80 is commonly used to identify macrophages in the female reproductive tract $[12,71-73]$. We recently showed that VEGFR- $1^{+}$ECs are often in direct contact with CD11b

${ }^{+}$monocytes/macrophages and $\mathrm{F} 4 / 80^{+}$macrophages in the peri-implantation uterus [ 12]. Blockade of VEGFR1 significantly decreases both the number macrophages in the decidua of E7.5 pregnant mice, likely as an indirect result of the decrease in VEGFR-1 function in ECs [ 12]. Here we show F4/80 $0^{+}$macrophages in direct contact with Notch $^{+}$vessels prior to implantation. Available data suggest that macrophages do not have an obligatory role in uterine decidualization and embryo implantation [ 12,71]. However, macrophages are implicated in trophoblast invasion and spiral artery remodeling during placental development [ 74, 75].

\section{Conclusions}

Taken together, our findings support unique roles for Notch1, Notch4 and angiogenic ligands, Dl14 and Jag1 in decidual angiogenesis. Abnormal decidual angiogenesis can result in spontaneous miscarriages early in pregnancy or have adverse "ripple effects" throughout pregnancy, leading to abnormal placentation, fetal growth restriction, and/or preeclampsia [1]. Proper trophoblast invasion of maternal spiral arteries in the uterine decidua is integral to placenta formation. Notch proteins are implicated in EC-trophoblast interactions during this vascular remodeling in the uterine decidua [ 76]. Our data set the stage for genetic studies to evaluate the requirement for Notch signaling in decidual angiogenesis and early placentation.

\section{Abbreviations}

- ECs: endothelial cells

- Dll4: Delta-like 4

- Jag1: Jagged 1

- NG2: neural/glial antigen 2

- PDGFR-ß: platelet-derived growth factor receptor beta

- SMA: alpha smooth muscle actin

- uSMCs: uterine smooth muscle cells

- vSMCs: vascular smooth muscle cells

- VEGFR: vascular endothelial growth factor receptor

- YFP: yellow fluorescent protein

\section{Declarations}

\section{Acknowledgments}

\section{Additional files}

Additional file 1: Figure S1.

Notch1 expression in patent capillaries in the pre-implantation uterus at E3.5. Notch1 expression is detected in capillaries containing FITC-dextran. The area in the rectangle is magnified and shown in 


\section{Competing interests}

The authors declare that they have no competing interests.

\section{Authors' contributions}

CJS participated in study design, data analysis, and manuscript preparation. LL and MG participated in data collection and imaging. MVS participated in manuscript preparation. VEP participated in data analysis and manuscript preparation. JKK participated in study design and manuscript preparation. NCD participated in study design, data analysis, and manuscript preparation. All authors read and approved the final manuscript.

\section{References}

1. Cha J, Sun X, Dey SK. Mechanisms of implantation: strategies for successful pregnancy. Nat Med. 2012;18:1754-1767.

View Article Google Scholar

2. Dey SK, Lim H, Das SK, Reese J, Paria BC, Daikoku T, et al. Molecular cues to implantation. Endocr Rev. 2004;25:341-373.

View Article Google Scholar

3. Wang H, Dey SK. Roadmap to embryo implantation: clues from mouse models. Nat Rev Genet. 2006;7:185-199.

View Article Google Scholar

4. Plaisier M. Decidualisation and angiogenesis. Best Pract Res Clin Obstet Gynaecol. $2011 ; 25: 259-271$.

View Article Google Scholar

5. Rockwell LC, Pillai S, Olson CE, Koos RD. Inhibition of vascular endothelial growth factor/vascular permeability factor action blocks estrogen-induced uterine edema and implantation in rodents. Biol Reprod. 2002;67:1804-1810.

View Article Google Scholar

6. Sengupta J, Lalitkumar PG, Najwa AR, Charnock-Jones DS, Evans AL, Sharkey AM, et al. Immunoneutralization of vascular endothelial growth factor inhibits pregnancy establishment in the rhesus monkey (Macaca mulatta). Reproduction. 2007;133:1199-1211.

View Article Google Scholar

7. Douglas NC Tang H Gomez R Pytowski B Hicklin DJ Sauer CM Vascular endothelial growth factor receptor 2 (VEGFR-2) functions to promote uterine decidual angiogenesis during early pregnancy in the mouse Endocrinology 20091508384538542717882 10.1210/en.2008-1207

8. Kim M Park HJ Seol JW Jang JY Cho YS Kim KR VEGF-A regulated by progesterone governs uterine angiogenesis and vascular remodelling during pregnancy EMBO Mol Med 201359141514303799495 10.1002/emmm.201302618

9. Maynard S, Epstein FH, Karumanchi SA. Preeclampsia and angiogenic imbalance. Annu Rev Med. 2008;59:61-78.

View Article Google Scholar

10. Ribatti D, Crivellato E. "Sprouting angiogenesis", a reappraisal. Dev Biol. 2012;372:157-165. View Article Google Scholar 
11. Rabbani ML, Rogers PA. Role of vascular endothelial growth factor in endometrial vascular events before implantation in rats. Reproduction. 2001;122:85-90.

View Article Google Scholar

12. Douglas NC Zimmermann RC Tan QK Sullivan-Pyke CS Sauer MV Kitajewski JK VEGFR-1 blockade disrupts peri-implantation decidual angiogenesis and macrophage recruitment Vasc Cell 20146164122670 10.1186/2045-824X-6-16

13. Suchting S Freitas $C$ Noble F Benedito R Breant C Duarte A The Notch ligand Delta-like 4 negatively regulates endothelial tip cell formation and vessel branching Proc Natl Acad Sci U S A 20071049322532301805603 10.1073/pnas.0611177104

14. Hellstrom M, Phng LK, Hofmann JJ, Wallgard E, Coultas L, Lindblom P, et al. Dll4 signalling through Notch1 regulates formation of tip cells during angiogenesis. Nature. 2007;445:776780 .

View Article Google Scholar

15. Lobov IB Renard RA Papadopoulos N Gale NW Thurston G Yancopoulos GD Delta-like ligand 4 (Dll4) is induced by VEGF as a negative regulator of angiogenic sprouting Proc Natl Acad Sci U S A 20071049321932241805530 10.1073/pnas.0611206104

16. Patel NS, Li JL, Generali D, Poulsom R, Cranston DW, Harris AL. Up-regulation of delta-like 4 ligand in human tumor vasculature and the role of basal expression in endothelial cell function. Cancer Res. 2005;65:8690-8697.

View Article Google Scholar

17. Shawber CJ Funahashi Y Francisco E Vorontchikhina M Kitamura Y Stowell SA Notch alters VEGF responsiveness in human and murine endothelial cells by direct regulation of VEGFR-3 expression J Clin Invest 200711711336933822030453 10.1172/JCI24311

18. Harrington LS, Sainson RC, Williams CK, Taylor JM, Shi W, Li JL, et al. Regulation of multiple angiogenic pathways by Dll4 and Notch in human umbilical vein endothelial cells.

Microvasc Res. 2008;75:144-154.

View Article Google Scholar

19. Funahashi Y Shawber CJ Vorontchikhina M Sharma A Outtz. HH Kitajewski J Notch regulates the angiogenic response via induction of VEGFR-1 J Angiogenes Res 201021 32828996 10.1186/2040-2384-2-3

20. Taylor KL, Henderson AM, Hughes CC. Notch activation during endothelial cell network formation in vitro targets the basic HLH transcription factor HESR-1 and downregulates VEGFR-2/KDR expression. Microvasc Res. 2002;64:372-383.

View Article Google Scholar

21. Liu ZJ Shirakawa T Li Y Soma A Oka M Dotto GP Regulation of Notch1 and Dll4 by vascular endothelial growth factor in arterial endothelial cells: implications for modulating arteriogenesis and angiogenesis Mol Cell Biol 20032311425140667 10.1128/MCB.23.1.14-25.2003

22. Shawber CJ, Kitajewski J. Notch function in the vasculature: insights from zebrafish, mouse and man. Bioessays. 2004;26:225-234.

View Article Google Scholar

23. Kofler NM Shawber CJ Kangsamaksin T Reed HO Galatioto J Kitajewski J Notch signaling in developmental and tumor angiogenesis Genes Cancer 20112121106 $1116341112410.1177 / 1947601911423030$

24. Limbourg FP Takeshita K Radtke F Bronson RT Chin MT Liao JK Essential role of endothelial Notch1 in angiogenesis Circulation 200511114182618322633594 
25. Uyttendaele H, Marazzi G, Wu G, Yan Q, Sassoon D, Kitajewski J. Notch4/int-3, a mammary proto-oncogene, is an endothelial cell-specific mammalian Notch gene. Development. 1996;122:2251-2259.

View Article Google Scholar

26. Villa N, Walker L, Lindsell CE, Gasson J, Iruela-Arispe ML, Weinmaster G. Vascular expression of Notch pathway receptors and ligands is restricted to arterial vessels. Mech Dev. 2001;108:161-164.

View Article Google Scholar

27. Loomes KM, Taichman DB, Glover CL, Williams PT, Markowitz JE, Piccoli DA, et al. Characterization of Notch receptor expression in the developing mammalian heart and liver. Am J Med Genet. 2002;112:181-189.

View Article Google Scholar

28. Joutel A Andreux F Gaulis S Domenga V Cecillon M Battail N The ectodomain of the Notch3 receptor accumulates within the cerebrovasculature of CADASIL patients J Clin Invest 20001055597605289174 10.1172/JCI8047

29. Hofmann JJ Luisa I-AM Notch expression patterns in the retina: An eye on receptorligand distribution during angiogenesis Gene Expr Patterns 2007744614703184647 10.1016/j.modgep.2006.11.002

30. Krebs LT Xue Y Norton CR Shutter JR Maguire M Sundberg JP Notch signaling is essential for vascular morphogenesis in mice Genes Dev 2000141113431352316662

31. Krebs LT Starling C Chervonsky AV Gridley T Notch1 activation in mice causes arteriovenous malformations phenocopied by ephrinB2 and EphB4 mutants Genesis 2010 4831461502849749

32. Uyttendaele H Ho J Rossant J Kitajewski J Vascular patterning defects associated with expression of activated Notch4 in embryonic endothelium Proc Natl Acad Sci U S A 2001 98105643564833266 10.1073/pnas.091584598

33. Domenga V Fardoux P Lacombe P Monet M Maciazek J Krebs LT Notch3 is required for arterial identity and maturation of vascular smooth muscle cells Genes Dev 20041822 $2730273552889310.1101 /$ gad.308904

34. Liu H Zhang W Kennard S Caldwell RB Lilly B Notch3 is critical for proper angiogenesis and mural cell investment Circ Res 201010778608702948576

10.1161/CIRCRESAHA.110.218271

35. Joutel A, Corpechot C, Ducros A, Vahedi K, Chabriat H, Mouton P, et al. Notch3 mutations in CADASIL, a hereditary adult-onset condition causing stroke and dementia. Nature. 1996;383:707-710.

View Article Google Scholar

36. Joutel A Monet M Domenga V Riant F Tournier-Lasserve E Pathogenic mutations associated with cerebral autosomal dominant arteriopathy with subcortical infarcts and leukoencephalopathy differently affect Jaggedl binding and Notch3 activity via the RBP/JK signaling Pathway Am J Hum Genet 20047423383471181931 10.1086/381506

37. Garcia-Pascual CM, Ferrero H, Zimmermann RC, Simon C, Pellicer A, Gomez R. Inhibition of Delta-like 4 mediated signaling induces abortion in mice due to deregulation of decidual angiogenesis. Placenta. 2014;35:501-508.

View Article Google Scholar 
38. Nowotschin $S$ Xenopoulos $P$ Schrode $N$ Hadjantonakis AK A bright single-cell resolution live imaging reporter of Notch signaling in the mouse BMC Dev Biol 201313153663770 $10.1186 / 1471-213 X-13-15$

39. Vorontchikhina MA, Zimmermann RC, Shawber CJ, Tang H, Kitajewski J. Unique patterns of Notch1, Notch4 and Jagged1 expression in ovarian vessels during folliculogenesis and corpus luteum formation. Gene Expr Patterns. 2005;5:701-709.

View Article Google Scholar

40. Murtomaki A Uh MK Choi YK Kitajewski C Borisenko V Kitajewski J Notch1 functions as a negative regulator of lymphatic endothelial cell differentiation in the venous endothelium Development 201314011236523763653558 10.1242/dev.083865

41. Parr MB, Parr EL. Permeability of the primary decidual zone in the rat uterus: studies using fluorescein-labeled proteins and dextrans. Biol Reprod. 1986;34:393-403.

View Article Google Scholar

42. Plaks V, Kalchenko V, Dekel N, Neeman M. MRI analysis of angiogenesis during mouse embryo implantation. Magn Reson Med. 2006;55:1013-1022.

View Article Google Scholar

43. Li S Li T Luo Y Yu H Sun Y Zhou H Retro-orbital injection of FITC-dextran is an effective and economical method for observing mouse retinal vessels Mol Vis 2011173566 35733250377

44. Chung AS, Ferrara N. Developmental and pathological angiogenesis. Annu Rev Cell Dev Biol. 2011;27:563-584.

View Article Google Scholar

45. Oliver G. Lymphatic vasculature development. Nat Rev Immunol. 2004;4:35-45.

View Article Google Scholar

46. Rosmarin AG, Weil SC, Rosner GL, Griffin JD, Arnaout MA, Tenen DG. Differential expression of CD11b/CD18 (Mo1) and myeloperoxidase genes during myeloid differentiation. Blood. 1989;73:131-136.

View Article Google Scholar

47. Keenihan SN, Robertson SA. Diversity in phenotype and steroid hormone dependence in dendritic cells and macrophages in the mouse uterus. Biol Reprod. 2004;70:1562-1572.

View Article Google Scholar

48. De M, Choudhuri R, Wood GW. Determination of the number and distribution of macrophages, lymphocytes, and granulocytes in the mouse uterus from mating through implantation. J Leukoc Biol. 1991;50:252-262.

View Article Google Scholar

49. De M, Wood GW. Analysis of the number and distribution of macrophages, lymphocytes, and granulocytes in the mouse uterus from implantation through parturition.J Leukoc Biol. 1991;50:381-392.

View Article Google Scholar

50. Brandon JM. Macrophage distribution in decidual tissue from early implantation to the periparturient period in mice as defined by the macrophage differentiation antigens F4/80, macrosialin and the type 3 complement receptor.J Reprod Fertil. 1995;103:9-16. View Article Google Scholar

51. Schroedl F, Brehmer A, Neuhuber WL, Kruse FE, May CA, Cursiefen C. The normal human choroid is endowed with a significant number of lymphatic vessel endothelial hyaluronate 
receptor 1 (LYVE-1)-positive macrophages. Invest Ophthalmol Vis Sci. 2008;49:5222-5229.

View Article Google Scholar

52. Liu H Kennard S Lilly B NOTCH3 expression is induced in mural cells through an autoregulatory loop that requires endothelial-expressed JAGGEDI Circ Res 20091044 4664752747310 10.1161/CIRCRESAHA.108.184846

53. Afshar Y Jeong JW Roqueiro D DeMayo F Lydon J Radtke F Notch1 mediates uterine stromal differentiation and is critical for complete decidualization in the mouse FASEB J 20122612822943250240 10.1096/fj.11-184663

54. Afshar Y Miele L Fazleabas AT Notch1 is regulated by chorionic gonadotropin and progesterone in endometrial stromal cells and modulates decidualization in primates Endocrinology 20121536288428963359612 10.1210/en.2011-2122

55. Gale NW Dominguez MG Noguera I Pan L Hughes V Valenzuela DM Haploinsufficiency of delta-like 4 ligand results in embryonic lethality due to major defects in arterial and vascular development Proc Natl Acad Sci U S A 2004101451594915954524697 10.1073/pnas.0407290101

56. Shutter JR Scully S Fan W Richards WG Kitajewski J Deblandre GA Dll4, a novel Notch ligand expressed in arterial endothelium Genes Dev 2000141113131318316657

57. Xue Y, Gao X, Lindsell CE, Norton CR, Chang B, Hicks C, et al. Embryonic lethality and vascular defects in mice lacking the Notch ligand Jagged1. Hum Mol Genet. 1999;8:723730 .

View Article Google Scholar

58. Krebs LT Shutter JR Tanigaki K Honjo T Stark KL Gridley T Haploinsufficient lethality and formation of arteriovenous malformations in Notch pathway mutants Genes Dev $200418202469247352953310.1101 /$ gad.1239204

59. Duarte A Hirashima M Benedito R Trindade A Diniz P Bekman E Dosage-sensitive requirement for mouse Dll4 in artery development Genes Dev 200418202474 2478529534 10.1101/gad.1239004

60. Red-Horse K Lymphatic vessel dynamics in the uterine wall Placenta 200829 Suppl A S55 S592435487 10.1016/j.placenta.2007.11.011

61. Volchek M, Girling JE, Lash GE, Cann L, Kumar B, Robson SC, et al. Lymphatics in the human endometrium disappear during decidualization. Hum Reprod. 2010;25:2455-2464.

View Article Google Scholar

62. Rogers PA, Donoghue JF, Walter LM, Girling JE. Endometrial angiogenesis, vascular maturation, and lymphangiogenesis. Reprod Sci. 2009;16:147-151.

view Article Google Scholar

63. Donoghue JF, Lederman FL, Susil BJ, Rogers PA. Lymphangiogenesis of normal endometrium and endometrial adenocarcinoma. Hum Reprod. 2007;22:1705-1713.

View Article Google Scholar

64. Koukourakis MI Giatromanolaki A Sivridis E Simopoulos C Gatter KC Harris AL LYVE1 immunohistochemical assessment of lymphangiogenesis in endometrial and lung cancer J Clin Pathol 20055822022061770560 10.1136/jcp.2004.019174

65. Fest S, Aldo PB, Abrahams VM, Visintin I, Alvero A, Chen R, et al. Trophoblast-macrophage interactions: a regulatory network for the protection of pregnancy. Am J Reprod Immunol. 2007;57:55-66.

View Article Google Scholar 
66. Kabawat SE Mostoufi-Zadeh M Driscoll SG Bhan AK Implantation site in normal pregnancy. A study with monoclonal antibodies Am J Pathol 1985118176841887848

67. Hunt JS. Cytokine networks in the uteroplacental unit: macrophages as pivotal regulatory cells. J Reprod Immunol. 1989;16:1-17.

View Article Google Scholar

68. Mor G Abrahams VM Potential role of macrophages as immunoregulators of pregnancy Reprod Biol Endocrinol 20031119305335 10.1186/1477-7827-1-119

69. Lessin DL, Hunt JS, King CR, Wood GW. Antigen expression by cells near the maternal-fetal interface. Am J Reprod Immunol Microbiol. 1988;16:1-7.

View Article Google Scholar

70. Vince GS, Starkey PM, Jackson MC, Sargent IL, Redman CW. Flow cytometric characterisation of cell populations in human pregnancy decidua and isolation of decidual macrophages. $J$ Immunol Methods. 1990;132:181-189.

View Article Google Scholar

71. Care AS Diener KR Jasper MJ Brown HM Ingman WV Robertson SA Macrophages regulate corpus luteum development during embryo implantation in mice J Clin Invest 20131238347234873726148 10.1172/JCI60561

72. De M, Wood GW. Influence of oestrogen and progesterone on macrophage distribution in the mouse uterus. J Endocrinol. 1990;126:417-424.

View Article Google Scholar

73. Turner EC Hughes $J$ Wilson H Clay M Mylonas KJ Kipari T Conditional ablation of macrophages disrupts ovarian vasculature Reproduction 201114168218313101494 10.1530/REP-10-0327

74. Spaans F, Melgert BN, Chiang C, Borghuis T, Klok PA, Vos P, et al. Extracellular ATP decreases trophoblast invasion, spiral artery remodeling and immune cells in the mesometrial triangle in pregnant rats. Placenta. 2014;35:587-595.

View Article Google Scholar

75. Grasso E Paparini D Hauk V Salamone G Leiros CP Ramhorst R Differential migration and activation profile of monocytes after trophoblast interaction PLoS One 201495 e971474029600 10.1371/journal.pone.0097147

76. Hunkapiller NM Gasperowicz M Kapidzic M Plaks V Maltepe E Kitajewski J A role for Notch signaling in trophoblast endovascular invasion and in the pathogenesis of preeclampsia Development 201113814298729983119307 10.1242/dev.066589 